\title{
“Ahkâmın Değişmesi”ne Farklı Bir Yaklaşım
}

\author{
Yrd. Doç.Dr. İbrahim ÖZDEMİR *
}

Öz: Şerî̀ hükümde değişim konusu birçok çalışmada usulî temelinden bağımsız olarak ele alınmaktadır. Bu konu, olguda değişimi esas alan ve her bir vakıanın alacağı hükmün illetini inceleyen tahkîku’l-menât yöntemi kapsamında ele alınmalıdır. Hükümde değişim kavramı, gerçek anlamda bir değişimi ifade etmemektedir. Bu değişimin ispatı için referans gösterilen tüm argüman ve örnekler bu anlamdaki değişimi değil, hükme konu olan cüzî̀ hâdiselerdeki değişimi ifade etmektedir. Cüzî̀ hadiselerin içerdiği tikel durumlar hükümlerin bağlandığı illetlere tekabül etmektedir. Hükümler illetlerle birlikte deveran ettiği gibi, bu tikel durumlarla birlikte de deveran etmektedir. Karâfî (ö. 684/1285)'den İbn 'Âbidîn (ö.1252/1836)'e kadar bu konuda söz söyleyen fakihler ahkâmın değişmesinden değil, ahkâma tekabül eden mezkûr durumların değişiminden bahsetmektedirler.

Anahtar Kelimeler: Hükümde değişim, Fetvada değişim, Tikel durum, Tahkîku'l-menât.

\section{A New Approach to the Concept of a Change in the Judgement}

\begin{abstract}
The subject of 'change in Shari 'a decision' is covered independently in many studies from the pertinent fundamental Sharia law. This subject has to be evaluated under the heading of 'tahqiq al-mana't which specifically examines a change in phenomenon and serves to determine the reason (illat) on which the decision for each daily-life case is based on. The concept of a change in the judgement does not mean a change in fundamental Sharia law. All of the arguments as well as examples referred to for proving a 'change in Sharia decision' only mean a change in daily-life individual cases, not a change in fundamental Shari law. Individual daily-life cases correspond to the Shar'i reasons on which decisions are based on. Decisions become different with reasons as well as with individual daily-life cases. All jurists from Karâfî to İbn 'Âbidîn discuss a change in phenomenon, not a change in fundamental Sharia law.
\end{abstract}

Keywords: Change in decision, Change in fatwa, Real (ized) case, Tahqiq al-menât

\section{Giriş}

Şer'î hükümlerle ilgili son dönemlerde tartışılan konuların başında değişim gelmektedir. Kuşkusuz bu tartışmanın arka planında ilmî, fikrî, iktisadî, ictimaî vb. birçok neden yatmaktadır. Ancak biz burada mezkûr nedenler yerine, şer’î hükümde değişim konusunun pek de üzerinde durulmayan bir yönü üzerinde durmak istiyoruz. O da, birçok çalışmada şer'î hükümde değişim olarak kabul edilen hususun, gerçek anlamda değişimi ifade edip etmediğidir. Nitekim bu konuda yapılan çalışmalara bakıldığında, burada üzerinde duracağımız hususun fazlaca irdelenmediği ve tartışmanın, değişime kapalı olan ve olmayan şer’̂̀ hükümlerin nitelik ve nicelikleri hakkında yoğunlaştı̆̆ görülür.1

* Bingöl Üniversitesi İlâhiyat Fakültesi İslam Hukuku Anabilim Dalı.

1 bk. Erdoğan, Mehmet, İslam Hukukunda Ahkâmın Değgşmesi, İstanbul 1994, s.100-134; Ğarayânî, Sadık Abdurrah- 
Çalışmamızda ele alacağımız hususun doğru anlaşılabilmesi için, aşağıda yer verilecek olan iki temel konunun yeterince bilinmesi gerekmektedir. Bu konulardan biri, hükümde değişimi kabul edenlerce sıklıkla başvurulan argümanların, bu anlamdaki değişimi ifade edip etmediğini ortaya koymaktır. İkincisi ise, mezkûr argümanların, hükmün değişimi yerine, vakıanın/olgunun değişimini esas alan ve "ve her bir vakıanın alacağı hükmün illetini inceleyen" ${ }^{2}$ tahkîku'l-menât yöntemi kapsamında ele alınmasının imkânı ve/veya zarureti üzerinde durmaktır. Nitekim çalışmamızın bir amacı da, hükümde değişim diye sunulan hususa bu yöntem perspektifinden bakmak ve bunu ilgili araştırmacıların dikkatine sunmaktır. Konumuz temelde usulî bir mahiyete sahip olduğundan çalışmamızda daha çok meselenin usulî boyutlarına yer verilecektir. Burada ele alınan temel konulara geçmeden, bu konuların ama temasını oluşturan hükümde değişimin mahiyetine değinmek istiyoruz.

Çalışmamızda irdelenen konuların odak noktasında yer alan değişim kavramı değişik çalışmalarda değişik tanımlara konu olmaktadır. Bu tanımlara bakıldığında onların, "bir hükmün diğer bir hükme dönüşmesi” veya "bir hükmün diğer bir hükmün yerini alması" anlamı üzerinde birleştikleri görülür. ${ }^{3}$ Şer’î hükümde değişimin gerekliliğinden bahseden ve aşağıda yer verilen yaygın fikhî kuraldan kast edilen de bu anlamdır. ${ }^{4}$ Isşte çalışmamızda bu anlamın gerçekte bir değişim olup olmadığı ve bunun yerleşik usulde hangi bağlamda veya kapsamda ele alınması gerektiği hususunu irdelemek istiyoruz. Şimdi asıl konumuza geçebiliriz.

\section{I. Şer'î Hükmün Değişimine Dair İleri Sürülen Deliller}

Bu başlık altında, şer’î hükümde değişim konusunu savunanlarca sıklıkla referans gösterilen argümanlara yer verilecek ve bunların konuya ait olup olmadığı irdelenecektir. Şer’î hükümde değişimi konu edinen hemen her çalışmada görülebilen bu argümanları şöyle sıralayıp ele almamiz mümkündür:

\section{A. Fetvanın Değişebilirliği}

Hükümde değişimi savunanların istidlâl ettikleri delillerin başında fetvada değişim konusu gelmektedir. Bu istidlâlde bulunanlara göre fetvada değişim şer'î hükümde değişimi ifade etmektedir. ${ }^{5}$ Ancak bu hususun gerçeği yansıtıp yansıtmadı̆̆ 1 , fetvada değişimle hükümde değişim kavramlarının özdeş olup olmadığı veya ilkinin diğerini gerektirip gerektirmediğinin bilinmesiyle ortaya çıkmaktadır. Şimdi bu konuya yakından bakmaya çalışalım.

Cüzî-amelî bir soruna ilişkin şer'î bir beyan ${ }^{6}$ şeklinde tanımlanabilen fetva, dört aşamadan oluşmaktadır. ${ }^{7}$ Birinci aşama, amelî sorunun fakih tarafından tasvir edilmesidir. Zira herhangi

man, el-Hükmü’s-şer'iyyu beyne’n-nakli ve'l-akl, Beyrut 1989, s. 311-324.

2 Âmidî, Ali b. Muhammed, el-İhkâm fî Usûli’l-Ahkâm, tlk., Abdurazzak 'Âfifî, Beyrut 1402, c. 3, s. 302.

3 bk. Na’rânî, Halil Mahmud, Eseru'z-Zarf fî Tağyîri'l-Ahkâmi’ş-Şer'iyye, Nablus 2003, s. 97-101; Erdoğan, İslam Hukukunda Ahkâmın Değişmesi, s. 87-89; Mikdaş, Süha Selim, Tağayyürü'l-Ahkam fi'l-Fıkhi'l-İslamî (Dirase Tatbikiyye li Kaideti "Lâ Yünkeru Tağayyyüru'l-Ahkam bi Tağayyüri'l-Ezmân”), Beyrut 2007, s. 33; es-Senûsî, Abdurrahman, I'tibarâtu'l-Meâlât ve Mura'âtu Netâici't-Tasarrufât, y.y., 1424, s. 413; Ebu Sünne, Ahmed Fehmî, el-Örfü ve'l-Âdetu fî R'eyi'l-Fukahâ, Kahire 2004, s.161.

4 bk. Hâdimî, Ebu Said Muhammed, Menâfiu'd-Dekâik fî Şerhi Mecâmi'i'l-Hakâik, İstanbul 1305, s. 328.

5 bk. Mensî, Muhammed Kasım, Tağayyürü'z-Zurûf ve Eseruhu fî İhtilafi'l-Ahkâm, Kahire 2010, s. 61.

6 Reysûnî, Kutub, Sinâatu'l-Fetva fi'l-Kadâya'l-Mu'âsıra, Beyrut 2014, s. 35.

7 bk. Cuma, Ali, et-Te'sîlu'l-Hadarî li’t-Teşrî̀i'l-İslamî (Tağayyürü'l-Fetva), http://pathlandmarks.blogspot.com. tr/2012/01blog-post.html. 
bir konuda olumlu veya olumsuz hükümde bulunabilmek için, o konunun tasavvur edilip diğer konulardan ayrışması gerekmektedir. ${ }^{8}$ Mantıkta yer alan "her ihtiyarî fiil tasavvur edildikten sonra varlık bulur"9 anlamındaki söz, bu hususu vurgulamaktadır. Bu aşama, ilgili sorunun fakih tarafindan fark edilmesine yönelik zihinsel bir durumu ifade etmektedir.

İkinci aşama, ilgili sorunun fakih tarafından bir keyfiyete kavuşturulmasıdır. Bu aşamadan kast edilen husus, ilgili sorunun fikhın hangi babına dâhil olduğunu belirlemektir. ${ }^{10}$ Çünkü amelî-hukukî sorunlara dair farklı alanlar söz konusu olduğu gibi, bu alan ve sorunlara ait farklı nitelikler de söz konusudur. Bu nedenle çözüme bağlanması talep edilen sorunun, hangi baba dâhil olduğu veya ne tür bir niteliği haiz bulunduğu fakih tarafından idrak edilmesi gerekmektedir. Bir keyfiyete sahip olduğu bilinmeyen herhangi bir soruna dair doğru bir hüküm verilmesinin pratikte mümkün olmaması da bu gerekliliğin somut bir kanıtıdır.

Üçüncü aşama, hukukî soruna karşılık gelen şer’î hükmün fakih tarafından tespit edilmesidir. Zira şer'î hükmü tespit edilmeyen bir sorunun, tasvir edilmesi ve keyfiyetinin belirlenmesi fetvanın tahakkuku için yeterli değildir. Dördüncü aşama ise fakih tarafından tespit edilen hükmün hukukî soruna tatbik edilmek suretiyle sorunun çözüme kavuşturulmasıdır. Nitekim ilgili soruna ilişkin tespit edilen şer'î hüküm verilmeden, diğer aşamaların varlığı fetvanın tamamlanması için kâfi gelmemektedir. Bazı bilginlerin fetvaya getirdikleri, "şer’̂̀ hükmü, vakıaya inzal etmektir" ${ }^{11}$ şeklindeki tanım, fetvanın bu son aşamasını nazara vermektedir. Fetva, mezkûr aşamalardan da anlaşıldığı gibi, olgu ve değer olmak üzere iki boyutu ihtiva etmektedir. Yukarıda yer verilen aşamaların ilk ikisi, fetvanın olgu (ontolojik) boyutunu oluştururken; son ikisi değer (epistemolojik) boyutunu oluşturmaktadır.

Yukarıda kısaca beyan edilen aşamalar fetvanın oluşması için kâfi gelse de, onun değişmesi için kâfi gelmemektedir. Fetvada değişimin gerçekleşebilmesi için bu aşamaların yanı sıra, değişime etki eden birtakım müessir gerekçelerin de tahakkuk etmesi gerekmektedir. Fetvada değişimi iktiza eden bu gerekçelerin sayısında birtakım farklılıklar söz konusu olsa da ${ }^{12}$ biz burada, İbn Kayyim(ö. 751/1350)'in bu konuya ayırdığg başlıkta zikrettiği gerekçelere yer vermekle iktifa etmek istiyoruz. İbn Kayyim ilgili başlıkta zaman, mekân, durum, âdet ve niyetten oluşan beş temel gerekçeye yer vermektedir. ${ }^{13}$ Ancak fetvada değişime neden olan bütün bu gerekçeleri burada detaylı olarak ele almamız, çalışmamızın amacı dışında kalmaktadır. Çünkü buradaki temel amacımız fetvayı bütün yönleriyle ele almak değil, fetvada değişim argümanıyla aşağıda yer verilecek olan diğer argümanların, şer’̂̀ hükümde değişime tekabül edip etmediğini veya onu gerektirip gerektirmediğini beyan etmektir. Dolayısıyla çalışmamızda, mezkûr gerekçelerden her birine, konumuza sşık tutacak kadar yer verilecektir.

8 Reysûnî, Sinâatu'l-Fetva fi'l-Kadâya'l-Mu'âsıra, s.287.

9 Râzî, Kutbuddin Muhammed b. Muhammed, Levâmi'u’l-Esrâr fî Şerhi Metâli'i'l-Envâr, Matbaatu'l-Hâc Muharrem Efendi, y.y., 1303, s. 23.

10 bk. Allâm, Şevkî, Davâbitu'-İftâ fi'l-Vaki'i'l-Mu'âsır: Menheciyyetu Sina'ati'l-İftâ (3), http://www.ahram.org.eg/NewsPrint/288382.aspx.

11 Allâm, Davâbitu'-Iftâ fi'l-Vaki'i'l-Mu'âsır:Menheciyyetu Sina'ati'l-İftâ (3), http://www.ahram.org.Eg/NewsPrint /288382.aspx.

12 bk. Uraynî, Ahmed b. Süleyman, en-Nehcu'l-Akvâ fî Erkâni'l-Fetva, Riyad 2008, s.474-484; Yaman, Ahmet, Fikhın Sosyolojik Yürürlüğ̈̈ Bağlamında Fetvada Değişim, Diyanet İlmi Dergi, Nisan-Mayıs-Haziran 2014, 50/2, s.12-21.

13 İbn Kayyim, Ebu Abdillah, Muhammed b. Ebibekr, I’lâmu'l-Muvakki'în 'an Rabbi'l-Alemîn, thk., Muhammed Mu’tasım el-Bağdadî, Beyrut 1996, c.3, s.5. 


\section{Zamanın Değişmesi}

Fetvada değişim hususu sıklıkla zamanın değişmesine nispet edilmektedir. Ancak bu değişimden maksat bizzat zamanın değişmesi değil, insanların değişmesidir. Çünkü salt zaman mefhumu fetvanın değişmesi için bir gerekçe teşkil etmemektedir. İnsanlardaki değişimin zamana nispet edilmesi ise, bu değişimin zaman zarfı içinde gerçekleşmesinden kaynaklanmaktadır. Nitekim zaman mefhumu ile insanların değişmesi arasında, zarfla mazruf arasında var olan bir ilişki biçimi söz konusudur. "Zamanın değişmesi” ifadesindeki mecazî kullanıma imkân veren de bu ilişki biçimidir.

İnsanların değişmesi kavramından kast edilen anlama gelince bu kavram, her ne kadar İslam hukukçuları tarafından fesadu'z-zaman kavramıla tefsir edilip birtakım olumsuz niteliklere (ahlakî bozulmalara) hasredilmişse de $^{14}$ burada, olumlu ve olumsuz tüm müessir niteliksel değişim anlamında kullanılmaktadır. Çünkü fetvanın değişmesinde etkili olan, niceliksel değişim olmadığı gibi, salt olumsuz niteliksel değişim de değildir. Bilakis olumsuz niteliksel değişimin yanı sıra, olumlu niteliksel değişim de fetvanın değişmesine neden olabilmektedir. Bütün bu hususları dikkate aldığımızda, zamanın değişmesi kavramını, "insanların sahip oldukları bilgiler, fikirler, davranışlar, alışkanlıklar, nitelikler, eğilimler vb. hususların zaman içinde olumlu veya olumsuz yönde değişmesi” şeklinde anlamak mümkündür.

Çalışmamızda zamanın değişmesi kavramı bilginin değişmesini de içeren kapsamlı bir anlamda kullanılmaktadır. Bu nedenle bazı araştırmacılar tarafından ayrı bir başlık altında ele alınan bilginin değişmesi için burada ayrı bir başlığa gerek duyulmamıştır. Nitekim insanın, zaman içinde yeni bilgiler edinmesi ve eski bilgilerinin yeni bilgilerden ötürü değişmesi, mümkün olmaktan öte vaki bir durumdur. ${ }^{15}$ Binaenaleyh yanlış bilgilere bina edilen fetvaların zaman içinde değişmesi bu gerekçenin kapsamında mülahaza edilmelidir. Bazı eserlerde ayrı bir başlık altında zikredilen şahsın değişmesi ${ }^{16}$ kavramı da, aynı şekilde zamanın değişmesi kapsamında yer aldığından burada ayrı bir başlık altında zikredilmemiştir. Çünkü şahsın değişmesiyle kast edilen şey, biyolojik değişim değil, niteliksel değişimdir.

\section{Mekânın Değişmesi}

Fetvada değişim gerekçelerinden biri mekânın değişmesidir. Bu değişimden kast edilen de çevrenin değişmesidir. ${ }^{17}$ Zira çevrenin insan ilişkileri üzerinde önemli birtakım etkileri söz konusudur. Nitekim fikhî hükümlerin kırsaldan şehire, sıcak bölgeden soğuk bölgeye, İslam diyarından küfür diyarına nispetle birtakım farklılıklar arz etmesi ve bu farklılıkların fetvalara yansıması, bu gerekçenin fetvada meydana getirebileceği etkilerin birer örneğini teşkil etmektedir. Binaenaleyh fakihin karşılaştı̆̆ı amelî-hukukî sorunlarla alakalı verdiği fetvalarda çevre faktörünü göz önünde bulundurması zorunludur.

14 bk. İbn Abidîn, Muhammed Emîn, Neşru'l-Arffi Binâi Ba'di'l-Ahkâm ala'l-Örf(Macmu'atu Resâili İbn Abidîn içinde), İstanbul 1320, c. 2, s. 125; Zerkâ, Mustafa Ahmed, el-Medhalu'l-Fıkhiyyu'l-Âmm, Dimaşk 1968, c.2, s. 926; Na’rânî, Eseru'z-Zarffî Tă̆yîri'l-Ahkâmi'ş-Şer'iyye, s. 351.

15 bk. Reysûnî, Sinâatu'l-Fetva fi'l-Kadâya'l-Mu'âsıra, s.331-333; Yaman, Fıkhın Sosyolojik Yürürlüğü Bağlamında Fetvada Değișim, s.18.

16 bk. Allâm, Davâbitu'-Iftâfi'l-Vaki'il-Mu'âstr:MenheciyyetuSina’ati'l-İftâ(5),http://www.ahram.org.eg/NewsPrint/288382.aspx. 17 Allâm, Davâbitu'-İftâfi'l-Vaki'il-Mu'âsır:MenheciyyetuSina'ati'l-İftâ(5), http://www.ahram.org.eg/NewsPrint/288382.aspx. 


\section{Durum Değişmesi}

Fetvada değişime neden olan gerekçelerden biri de durumun değişmesidir. Bu kavram, insanın hayatta karşılaşabileceği her türlü müessir hal ve durumu ifade etmektedir. İkametle sefer, barışla savaş, sağlıkla hastalık, zenginlikle fakirlik, emniyetle korku, bollukla darlık, küçüklükle büyüklük vb. haller bu gerekçeyle alakalı insan aklına gelen ilk somut örneklerdir. Fakihin, karşılaştığı hukukî sorunlarda, mezkûr durumlardan kaynaklanan farklılıkları göz önünde bulundurup fetva vermesi gerekmektedir. Günümüzde çokça dillendirilen zaruret, ihtiyaç ve umûmu'lbelvâ gibi durumlar, bu gerekçe kapsamında yer aldığından çalışmamızda ayrı başlıklar altında ele alınmamıştır. ${ }^{18}$

\section{4.Örfün Değişmesi}

Fetvanın değişim gerekçelerinden biri, fetvaya konu olan amelî-hukukî sorunlarla alakalı örfün değişmesidir. ${ }^{19}$ Akitlerde ücretin ödenmesi, satılan nesnelerin alıcı tarafından görülmesi, yolda yürürken yemeğin yenilmesi, erkeklerin baş açı gezmesi vb. birçok konuda toplumdan topluma, bölgeden bölgeye, yöreden yöreye farklı örf ve âdetler söz konusudur. Fakih hukukî-örfî bir soruna çözüm üretmeye çalışırken sorun sahibinin ait olduğu toplumu, bölgeyi veya yöreyi dikkate almak durumundadır. ${ }^{20} \mathrm{Bu}$ da fetvanın örf ve âdete paralel olarak değişmesi sonucunu doğurmaktadır.

\section{Niyetlerin Değişmesi}

Fetvada değişimin bir gerekçesi de fetvaya konu olan fiil ve sözlerin bina edildiği niyetlerin değişmesidir. ${ }^{21} \mathrm{Bu}$ gerekçe daha çok akit ve sözlerden oluşan hukukî sorunlarda söz konusudur. Nitekim manaya delaleti niyetlere göre değişen hukukî sorunlar da genelde söz ve akitlerden oluşmaktadır. Yemin, nikâh, talak, nezir vb. akitlere ilişkin verilen fetvalarda söz konusu olan değişimler bu gerekçenin en çok vuku bulan örnekleri arasında yer almaktadır. ${ }^{22}$

Fetvada değişimin hükümde değişimi ifade edip etmediği konusuna gelince bu konuda şunları söylememiz mümkündür: Fetvanın yukarıda zikredilen tanımı, oluşum safhaları ve değişim gerekçelerine bakıldığında, fetva kavramının hüküm kavramından farklı olduğu görüldüğü gibi, fetvada değişim kavramının da hükümde değişim kavramından farklı olduğu görülür. Nitekim fetva netice itibariyle fakihin, cüzî-amelî bir sorunun şer'î hükmünden haber vermesidir. ${ }^{23}$ Her beşerî fiilde olduğu gibi bu içtihadî fiil de doğru veya yanlış olma ihtimalini barındırmaktadır. Bu ihtimalin şer’î hükümde söz konusu olmadığı ise bedihîdir. Müsbet durumda birbiriyle örtüşmeyen kavramların menfi durumda da birbirleriyle örtüşmeleri mümkün değildir. Mantıkta belirtildiği gibi bu husus kavramlar arası özdeşliğin tabiî bir sonucudur.

18 bk. Yaman, Fıkhın Sosyolojik Yürürlüğü Bağlamında Fetvada Değişim, s.19; Uraynî, en-Nehcu'l-Akvâ fî Erkâni'l-Fetva, s. 483; Bin Beyye, Abdullah, Sinâatu'l-Fetva ve Fıkhu'l-Evveliyyât, Cidde 2007, s. 215-217; Na'rânî, Eseru'z-Zarf fî̀ Tağyîri'l-Ahkâmi'ş-Şer'iyye, s. 295-348

19 bk. İbn Kayyim, I’lâmu'l-Muvakki'în, c.3,s.42; İbn Abidîn, Neşru’l-Arf, c. 2, s. 115-116; Ebu Sünne, el-Örfü ve’l-ÂAetu fî R'eyi'l-Fukahâ, s. 201.

20 bk. İbn Abidîn, Neşru'l-Arf, c. 2, s. 129.

21 İbn Kayyim, I'lâmu'l-Muvakki’în, c.3, s. 48.

22 bk. İbn Kayyim, İlâmu'l-Muvakki'în, c.3, s. 48-49; İbn Nüceym, Zeynüddin b.İbrahim, el-Eşbâh ve’n-Nezâir, thk., Muhammed Muti' Hafız, Dimașk 2005, s.101-114.

23 Karâfî,Şihâbuddin Ebu'l-Abbas Ahmed b. İdrîs, el-İhkâm fî Temyîzi'l-Fetavâ 'ani'l-Ahkâm ve Tasarrufati'l-Kâdî ve'lİmâm, thk., Abdulfettâh Ebu Ğudde, Beyrut 2009, s. 31, 33; Uraynî, en-Nehcu'l-Akvâ fî Erkâni’l-Fetva, s. 62. 
Fetvada değişim kavramı hükümde değişim kavramıyla özdeş olmadığı gibi, bu kavramı gerektirecek bir konuma da sahip değildir. Zira fetvada değişim, ilk bakışta hükmün değişimini gerektirdiği gibi görülse de, bu husus gerçeği yansıtmamaktadır. Çünkü fetvada değişimin gerektirdiği şey, hükmün değişimi değil, fetvaya konu olan tikel durum ve hadiselerin değişmesidir. Fetvaya konu olan durum ve hadiselerin değişmesi ise önceki hükümlerden farklı hükümleri beraberinde getirse de bu husus, zannedildiği gibi, hükümde değişimi netice vermez. Bilakis hükümde farklılığı veya hükümde deveranı beraberinde ki getirir ki, bu iki kavramın hükümde değişim kavramından farklı olduğu açıktır. Binaenaleyh fetva kavramıyla hüküm kavramını birbirinden tefrik ettiğimiz gibi, fetvada değişim kavramıla hükümde değişim kavramını da birbirinden tefrik etmemiz gerekmektedir. ${ }^{24}$ Nitekim bu ayrışmayı Karâfî̀nin, el-İhkâm fî Temyizi'l-Fetavâ 'ani'l-Ahkâm ve Tasarrufâti'l-Kâdî ve'l-İmâm adlı eserinin başlı̆̆ında da görmek mümkündür.

Sözü edilen iki kavram arasındaki farkı mantıkî önermelerle şöyle formüle edebiliriz: Her değişim bir farklılıktır. Ancak her farklılık bir değişim değildir. Bunu bir örnekle somutlaştırmak gerekirse, bolluk durumunda murdar etin yenmesi caiz değildir. Bolluk durumu zaruret veya darlık durumuyla yer değiștiğinde, mezkûr durumdan kaynaklanan haramlık hükmü kalkar ve murdar etin yenmesi helal olur. Bu değişim durumu zaruret hali için de aynen geçerlidir. Çünkü zaruret/ihtiyaç hali de bolluk durumuyla yer değişirse, murdar etin yenmesi tekrar haram hükmünü almış olur. Bu örneğe bakıldığında, değişime maruz kalanın, hüküm değil, hükme konu olan cüzî hadise veya durumlar olduğu açıkça görülür. Böylece fetvada değişimin, hükümde değişimi değil, hükümde farklılığı veya deveranı beraberinde getirdiği ve bunun da, ilk etapta bir değişim gibi görünse de, gerçekte böyle olmadığı ortaya çıkmış bulunmaktadır.

Binaenaleyh fetvada değişim argümanını ileri sürüp bununla hükümde değişimi ispata kalkışmak, yanlış bir istidlâlde bulunmak veya delili, medlulü dışında kullanmak anlamına gelmektedir. Karâfî̀den İbn 'Abidîn’e kadar bu konuda söz söyleyen bütün fakihler, aşağıda beyan edileceği gibi, eserlerinde yer verdikleri "hüküm ihtilaf eder veya hüküm tagayyür eder" şeklindeki ifadeleri, "hüküm vakıayla birlikte farklılaşır veya deveran eder" şeklinde anlaşılmalıdır. Bu hususu, mezkûr ifadelerin yer aldığı bağlamlardan ve verilen örneklerden de anlamak pekâlâ mümkündür.

Fetvada değişimle hükümde değişim arasında bir özdeşlik veya gerektirme durumunun bulunmadığı hususuna biraz daha yakından bakacak olursak şunları söyleyebiliriz: Fetva fer'îamelî sorunlara ait şer'î hükümlerin yetkin bir fakih tarafından beyan edilmesini ifade etmektedir. Fetvaya konu olan bu tür sorunlar, yukarıda beyan edilen birtakım nesnel gerekçelerden ötürü değişime maruz kalabilmektedir. Olgusal sorunlarda değişime maruz kalan şey, kemiyet değil, keyfiyete ilişkin durumlardır. Olgusal sorunlara ait niteliklerin değişmesi de, fetvada değişimi beraberinde getirmektedir. Zira fakih tarafından verilen fetvalar mezkûr niteliklere uygun olmak durumundadır. Diğer bir ifadeyle, olgusal sorunlarda meydana gelen niteliksel değişimler, fetvalara yansımak zorundadır. Nitekim yukarıda beyan edildiği gibi, tikel-olgusal hukukî bir sorun fetvaya konu edilirken, önce sorun tasvir edilip ortaya konulur. Sonra sorunun nitelikleri belirlenir. Nitelikler belirlendikten sonra her bir niteliğe uygun olan şer’̂̀ hüküm fakih tarafından tespit edilir ve ilgili sorun böylece çözüme kavuşmuş olur. Fetvanın oluşum sürecinde vuku bulan bütün bu aktiviteler ise, usul ilminde bir içtihat türü olarak kabul edilen "tahkîku’l-menât" 
yöntemine tekabül etmektedir. Bu da cüzî̀ olgusal durumlarda meydana gelen niteliksel değişimin, usulde beyan edilen illetlerin değişimine tekabül ettiği anlamına gelmektedir ki, her illet de, kendine has bir hükmü aldığı gibi ${ }^{25}$ her cüzî olgusal durum da kendine has bir hükmü almaktadır. Dolayısıyla fetvada değişim konusu hükümde değişim bağlamında değil, "tahkîku'l-menât" kapsamında ele alınmalıdır. Nitekim bu kapsamda ele alınan tikel-hukukî sorunlara bakıldığında, her tikel-hukukî sorunun taşıdığı özel nitelikten/illetten ötürü kendine özgü bir hükmü aldığı görülür. Çünkü bu yöntem, aynı tikel olgulara ait hükümlerin zaman içinde değişmesini değil, farklı nitelikleri içeren olgusal sorunların farklı hükümleri aldığını ifade etmektedir. ${ }^{26} \mathrm{Bu}$ yönteme dair geniş bilgi aşağıda verilecektir.

\section{B. Karâfi, Şâtıbî, İbn Kayyim, İbn 'Âbidîn Gibi Fakihlerin Değişime Dair Sözleri}

Şer'î hükümlerde değişimi savunanlar Karâfî, Şâtıbî(ö.790/1388), İbn Kayyim, İbn ‘Âbidîn gibi fakihlerin değişime dair sözlerini bu anlamdaki değişime birer kanıt olarak sunmaktadırlar. ${ }^{27}$ Bu istidlâllere göre mezkûr sözler şer'î hükümde değişimi ifade etmektedir. Bu başlık altında, başvurulan bu istidlâllerin yerinde olup olmadığı irdelenecek ve referans gösterilen sözlerin, gerçek anlamda hükümde değişimi ifade edip etmediği ortaya konacaktır. Değişim konusunda sözlerine başvurulan fakihlerin başında kuşkusuz İbn Kayyim gelmektedir. Bu nedenle burada ilk önce onun ifadelerine yer verilecektir.

Hükümde değişim konusunu savunanlar İbn Kayyim’in iki ifadesiyle istidlâl etmektedirler. Bunlardan biri, İbn Kayyim'in, I'lâmu'l-Muvakkîn'de fetvada değişim konusuna ayırdığı̆ başlıktır. Diğeri de İğasetu'l-Lehfân min Mesâidişs-Seytân isimli eserinde yer verdiği ifadedir. Şimdi bu iki ifadeye yer verip bunların hükümde değişime delalet edip etmediğine bakmaya çalışalım.

İbn Kayyim’in fetvada değişim bağlamında zikrettiği başlı şöyledir: "Bu bölüm fetvanın $z a$ man, mekân, durum, niyet ve âdetlerin değişmesiyle birlikte değişip farklılaşması hakkındadır."28 İbn Kayyim bu başlı̆ı̆n devamında, bu konunun önemine dair bazı temel bilgileri verdikten sonra, değişime konu olan birçok fetva örneğine yer vermektedir. Bu başlğ̆ın doğru bir biçimde anlaşılabilmesi için, ifadenin kendisine ve varit olduğu bağlama bakmak gerekmektedir. İfadenin kendisine bakıldığında onun, hükümde değişimle alakalı olmadığı rahatlıkla görülecektir. Zira ifadenin kendisi, hükümde değişime değil, fetvada değişime delalet etmektedir ki, fetvada değişimin hükümde değişimi ifade etmediği, bir önceki konuda delilleriyle birlikte beyan edilmiştir. Mezkûr ifadenin diğer yönünü oluşturan bağlamına bakıldığında ise, onun, fetvanın değişiminden ziyade, bu değişime neden olan fiilî durumların değişimine dair olduğu anlaşılacaktır. $\mathrm{Bu}$ da, daha önce ifade edildiği gibi, fetvaya konu olan olgusal sorunların tikel durumlarına tekabül etmektedir. Birçok eserde farklı isim ve sayıda yer bulan bu durumlar İbn Kayyim tarafından mezkûr başlıkta beş temel gerekçe halinde zikredilmektedir.

25 İbn Hâcib, Ebu Amr Osman, Münteha'l-Vusûl ve'l-Emel fi İlmeyi'l-Usûl ve'l-Cedel, Birinci Baskı, Matbaatu’s-Saâde, Misir 1326, s. 133.

26 bk. Binbeyye, Abdullah, el-İctihad bi Tahkîki'l-Menât: Fikhu'l-Vâki’ve't-Tevakku', http: // www. binbayyah. net/portal/ research/1148.

27 bk. Mensî, Tağayyürü'z-Zurûf ve Eseruhu fî İhtilafi'l-Ahkâm, s.58-62;Sevseve, Abdulmecid Muhammed, el-Hukmu'şŞer'iyyu Beyne’s-Sebâti ve’t-Tagayyür, Mecelletu’Ş-Şerîa ve'l-Kanun, Sayı 20, Eylül 2003,s.30; Devâlibî,, Maruf, Mecelletu el-Müsslimûn, Sayı, 6, Y1l 1, Mayıs 1952, s. 34.

28 İbn Kayyim, I'lâmu'l-Muvakkiî̀n, c. 3, s. 5. 
Başlığa usulî bir perspektiften bakmak gerekirse şunları söylememiz mümkündür: İbn Kayyim bu başlıkta, fetvanın değişmesini gerektiren zaman, mekân, durum, niyet ve âdet gibi değişim gerekçelerinden bahsetmekte ve her bir gerekçeye dair birtakım örnekler verip onları detaylı olarak incelemektedir. İbn Kayyim bir önceki fasılda fetvanın naslara aykırı olmaması üzerinde durmaktadır. ${ }^{29} \mathrm{Bu}$ fasılda ise fetvanın vaki duruma aykırı düşmemesi gerektiğini incelemektedir. Dolayısıyla bu başlıkta ifade edilmek istenen asıl konu vaki durumdur. Bu iki faslı birlikte düşündügüumüzde bir fetvanın sahih olabilmesi için iki temel şartı haiz olması gerektiği görülür. Biri naslara aykırı bulunmamasıdır. Diğeri de vaki duruma uygun olmasıdır. İbn Kayyim bu iki hususu, daha önce zikretmiş olduğu, "Müftî ve hâkim iki türlü anlayışa sahip olmakla doğru fetva ve hükümde bulunabilirler: Bunlardan biri vaki durumu anlamak, onu inceden inceye kavramak, karine, emare ve diğer alametlerle vaki olan tikel durumun niteliğini çıkarsamaktır. Bu şekilde ancak cüzî duruma dair kuşatıcı bir bilgi elde edilebilir. Diğeri de vaki duruma ilişkin vacib olanı anlamaktır. Bu da vaki durumla ilgili Kitab ve Sünnette varid olan hükmü iyice bilmekten ibarettir"30 şeklindeki sözlerini açıklarken ele almaktadır. Böylece İbn Kayyim’in, bu sözlerde teorik düzeyde yer verdiği iki temel konunun açılımını sağlamak için iki ana başlığa yer verdiği ortaya çıkmaktadır. Başlıkların birinde, fetvanın naslara aykırı olmaması gerektiği üzerinde dururken; diğerinde fetvanın vaki duruma uygun olması gerektiği üzerinde durmaktadır.

Bütün bu hususları göz önünde bulundurduğumuzda ilgili başlıkta, fetvadaki değişimden çok fetvanın reel duruma uygun olmasının gerekliliğinden bahsedildiğini söylemek mümkündür. İbn Kayyim'in fetvada değişimi gerektiren vaki durumu beş temel gerekçeye ayırması ve her bir gerekçeye dair geniş bilgi ve örneklere yer vermesi de bu gereklilikten ileri gelmektedir. İbn Kayyim'in, üzerinde durduğu vaki durumun bu gerekçeleri de,usulde hükmün dayanağını teşkil eden şer’î illetlere (menât) tekabül etmektedir. Binaenaleyh o, bu başlikta hükmün değişmesinden değil, hükmün gerekçesini oluşturan illetin değişmesinden bahsetmiş olmaktadır. İlletin değişmesi ise, ilk bakışta hükmün değişmesini beraberinde getirir gibi bir görüntü verse de, bu görüntü gerçeği yansıtmamaktadır. Çünkü yukarıda ifade edildiği gibi, her illetin kendine özgü bir hükmü bulunduğu gibi, illete tekabül eden her vaki durumun da kendine özgü bir hükmü bulunmaktadır. Bu hususu şöyle de formüle edebiliriz: Fetvada değişime neden olan, vaki durumlardır. Vaki durumlar usulde hükmün gerekçesi sayılan illetlere tekabül etmektedir. İlletlerle hükümler arasında var olan ilişkiye bakıldığında hükümlerin değil, illetlerin değiştiği görülür. O halde fetvada değişen hükümler değil, hükme gerekçe teşkil eden vaki durumlardır. Her vaki durum da kendine özgü olan hükmü almaktadır. Usulcülerin "şer’i hükümler varlıkta ve yoklukta illetlerle birlikte deveran etmektedir" ${ }^{31}$ anlamındaki sözleri, bütün bu hususları veciz bir biçimde ifade etmektedir.

Bu teorik bilgileri şöyle bir örnekle somutlaştırmak mümkündür: Üzüm helal bir gıda maddesidir. Üzümden içki üretilirse haram hükmünü alır. Üzümün içki hali sirke haliyle yer değişirse haramlık hükmü yerini helal hükmüne bırakır. Bu örneğe bakıldığında, değişime maruz kalanın, şer’i hükümler değil, bu hükümlere konu olan üzümün tikel vaki durumları/nitelikleri olduğu görülür. Nitekim üzümün dönüşebileceği her iki tikel durumun da kendine has tikel birer hükmü söz konusudur. Binaenaleyh her tikel vaki durum, birbirinden ayrı hükümleri almaktadır. Bu da,

29 bk. İbn Kayyim, İlâmu'l-Muvakki'în, c. 2, s. 247-384.

30 İbn Kayyim, I'lâmu'l-Muvakki'în, c.1, s. 69.

31 Kubeysî, Hamed Ubeyd, Usûlu'l-Ahkâm ve Turuku'l-İstinbât fi't-Teşrî̀il-İ́slamî, Dimaşk 2009, s. 121. 
İbn Kayyim'in mezkûr ifadesinin, hükümde değişim konusu bağlamında değil, vaki durumun değişimini temel alan tahkîku'l-menât yöntemi bağlamında ele alınması gerektiğini ortaya koymaktadır.

İlgili başlık altında fetvada değişimin temel gerekçeleriyle alakalı verilen bütün örnekleri burada ele almamız çalışmamızın sınırlarını aşacağı muhakkaktır. Bu nedenle sadece bir örnekle yetinmek istiyoruz. O da, Karâfi, Şâtıbî ve İbn 'Âbidîn tarafından da ele alınan örf ve âdetlere göre değişen niyet odaklı sözlerdir. İbn Kayyim’in yer verdiği bu örneği kısaca şöyle ifade edebiliriz:

Fetvada değişimi gerektiren cüzî vaki durumlardan biri örften örfe anlamları değişen lafızlardır. Bu tür lafızlar daha çok yemin, ikrar, vakıf, talak, nikâh, nezir vb. konularda söz konusudur. ${ }^{32}$ Bunun temel nedeni de, hükümlerin niyetlere bağlı olması ve niyetlerin de değişen örfî lafızlarla birlikte değişmesidir. Nitekim insanların kullandıkları lafızlar bölgeden bölgeye, yöreden yöreye hatta meslekten mesleğe değişebilmektedir. Binaenaleyh fakih bu tür hukukî sorunlarda kendisine başvuranın ait oldu örf ve âdetini dikkate alıp fetva vermek durumundadır. Sözgelimi, binek kelimesini merkep anlamında kullanılan bir yörede yaşayan biri "ben bineğe binmedim" diye yemin ederse, ata veya katıra binmesiyle yemini bozulmuş olmaz. Bu durum talak, nikâh, vakıf, nezir vb. alanlarda da söz konusudur. ${ }^{33}$

Bu alanlarla ilgili verilen fetvalardaki değişime gelince, bu değişimin vaki durumlardaki değişimden kaynaklandığını söylemek mümkündür. Zira hükümler anlamlara göre farklılaşırken anlamlar da niyetlere göre farklılaşmaktadır. ${ }^{34}$ Hükümlerin niyetlere göre farklılaşması ise niyetin, hükmün illeti olmasından kaynaklanmaktadır. Böylece bu örnekte sözü edilen değişimin hükümlerde değil, bu hükümlerin birer illeti konumunda bulunan tikel vaki durumlarda (niyetlerde) vuku bulduğu ortaya çıkmaktadır.

İbn Kayyim’in hükümde değişim için delil gösterilen, "Hükümler iki kısma ayrılmaktadır. Bunlardan biri, bir hal üzerine kalır. Zaman, mekân ve imamların içtihadına göre değişmez. Vaciblerin vacipliği, haramların tahrimi, şer' tarafindan suçlar için tahdit edilen cezalar vb. örnekler gibi. İkincisi de, zaman, mekân ve duruma göre maslahatın iktiza etmesi sonucu değişir. Tazire konu olan cezaların miktar, cins ve sıfatları gibi" ${ }^{35}$ şeklindeki ifadesine gelince, bu ifadeyi de hükümde değişim açısından şöyle değerlendirmek mümkündür:

Bu ifadenin yer aldığı bağlama bakıldığında İbn Kayyim’in, şu tespitlerde bulunduğu görülür: "Bilginler Hz. Ömer'in üç talakla boşanmayı bir talak sayması hakkında iki gruba ayrıltm mışlardır. Bir grup Hz. Ömer ve onun gibi düşünenler adına ilgili hadisleri te’vil etmişlerdir. Diğer grup ise ilgili hadisleri ileri sürerek Hz. Ömer'in yaptı̆̆ını mazur görmeye yönelmiş ve yukarıdaki ifadede belirtildiği üzere hükümleri iki kısma ayırmışlardır. Bu gruba göre Hz. Ömer’in üç talakla ilgili uygulaması tazir cezası kapsamına girmektedir ki, bu tür cezalarda devlet başkanı kamu maslahatı gereği birtakım değişikleri yapma salahiyetine sahiptir." ${ }^{36}$ İbn Kayyim bu tespitlerden sonra konuyla alakalı şu değerlendirmeye yer vermektedir: "Bu geniş bir konudur. Birçokları bu konuda,

32 bk. İbn Kayyim, İ'lâmu'l-Muvakki’̂̀n, c.3, s. 48-49.

33 bk. İbn Kayyim, İlâmu'l-Muvakki'în, c.3, s. 48-49, 88-89.

34 bk. Hasen, Mahmud Abdulkerim, Tahrifu'l-İslam bi Hücceti Tagayyüri'l-Ahkâm bi Tagayyüriz-Zemani ve'l-Mekan (2), http://sabiltahrir.blogspot.com.tr/2013/06/2.html.

35 İbn Kayyim, İ̆âsetu'l-Lehfân min Mesâyidi’ş-Şeytân, thk., Muhammed Hamid el-Fukâ, Riyad, ty., c. 2, s. 330.

36 İbn Kayyim, İğâsetu'l-Lehfân, c. 2, s. 330. 
sabit ve değişmez olan hükümlerle varlık ve yoklukta maslahatlara tabi olan tazir türü hükümleri birbirine karıştırmaktadırlar." ${ }^{37} \mathrm{Bu}$ değerlendirmede bulunan İbn Kayyim sözünü ettiği maslahat odaklı tazir cezaları için Hz. Ömer'in üç talakla ilgili uygulamasını örnek vermekte ve bu uygulamaya dair üç ihtimalin mümkün olduğunu söylemektedir. İbn kayyim’in dile getirdiği bu ihtimalleri şöyle özetlemek mümkündür: Hz. Ömer; Bu uygulamayı, içki içene vurulan seksen celdeyle birlikte başının tıraş edilmesi örneğinde görüldüğü gibi, ya ihtiyaç halinde arız olan bir tazir cezası olarak görmektedir; ya hac mut’asında olduğu gibi, üç talakın bir talak sayılmasını şarta bağlı bulunduğunu ve şartın da ortadan kalktığını zannetmektedir veyahut da üç talakı bir saymak için bir mâniin var olduğunu düşünmektedir. Nitekim hükümler, şartların yokluğuyla ortadan kalktığı gibi, manilerin varlığıyla da ortadan kalkmaktadır. ${ }^{38}$

İbn Kayyim'in mezkûr değerlendirmesine bakıldığında ilgili ifadenin, takdir ve uygulanması devlet başkanının inisiyatifine bırakılmış olan tazir türü cezalara dair olduğu, bu hükümlerin dışında kalan diğer hükümlerin ise, sabit olup değişmediği ve ancak bir şartın yokluğu veya mâniin varlığı durumunda uygulamadan kalkabileceği görülür. Binaenaleyh İbn Kayyim’in, hükümde değişim için referans gösterilen ikinci ifadesinin de bu konuyla ilgili olmadığı, bilakis hükmün illetini tespit etme işlevini gören tahkîku'l-menât yöntemi kapsamına giren cüzî olgusal durumlarla ilgili olduğu açıkça görülür. Böylece İbn Kayyim’in hükümde değişim için çokça referans gösterilen ifadelerinin bu anlamdaki değişimi ifade etmediği ve bu nedenle mezkûr ifadelerle yapılan istidlâlin yerinde bir istidlâl niteliğini taşımadığı ortaya çıkmaktadır. Şimdi de Karâfi, Şâtıbî ve İbn ‘Âbidîn’in hükümde değişim konusuna delil gösterilen sözlerini ele almaya çalışalım.

Karâfi'yle İbn ‘Âbidîn birbirine benzer ifadeler kullandıklarından önce bu iki fakihin ifadelerini ardarda ele aldıktan sonra Şâtıbînin ifadelerine yer vermek istiyoruz. Karâfi’nin hükümde değişim için referans gösterilen sözleri farklı eserlerinde yer almaktadır. Bunlardan biri belki de en önemlisi Furûk adlı eserinde yirmi sekizinci farkta zikredilen ifadelerdir. Karâfî burada lafızları tahsis eden müessir kavlî örf ile lafızlarda bu etkiyi yapmayan fiilî örfü birbirinden ayırmaktadır. ${ }^{39} \mathrm{O}$, burada yemine dair verdiği örneklerle iki ayrı hükmün varlığından söz etmektedir. Yeminde sözle fiili birbirinden ayırmayı da şu iki temele bina etmektedir: Birinci temel yemin lafzının genel veya özel manaya delalet etmesi. Diğeri de yemin eden şahsın kastı. ${ }^{40}$ Karâfı’nin bu meyanda yer verdiği bilgilerle zikrettiği örneklerden şunu anlamak mümkündür. Şâri’ birtakım hükümleri lafızların delaleti ve bu lafızları kullananların niyetlerine bağlamıştır. Delalet ve niyetler değiştikçe onlara bina edilen hükümler de farklılaşmaktadır. İlk bakışta delalet ve niyetlerde görülen değişimin bir benzerinin hükümlerde de var olduğu düşünülür. Ancak yukarıda ifade edildiği gibi bu düşünce doğru değildir. Zira bu tür lafızlarda söz konusu olan hükümler değişmemektedir. Belki birer illet konumunda olan delalet ve niyetlerle birlikte deveran etmektedir. Nitekim her bir niyet veya delaletin kendine has bir hükmü bulunmaktadır. Bu husus, yukarıda beyan edildiği gibi, delalet, niyet ve kasta bağlı olan tüm lafız ve akitler için de geçerlidir. Karâfi'nin burada dile getirdiği hususlar, yukarıda İbn Kayyim tarafından da dile getirilmiştir. Bu nedenle İbn Kayyim'in ifadeleriyle ilgili yapılan değerlendirme Karâfi'nin hatta biraz sonra ifadelerine yer verilecek olan İbn ‘Âbidîn ve Şâtıbînin sözleri için de aynen geçerlidir.

37 İbn Kayyim, İğâsetu'l-Lehfân, c. 2, s. 133.

38 bk. İbn Kayyim, İ̆âsetu'l-Lehfân, c. 2, s. 133-334.

39 bk.Karâfî, el-Furûk (İbnu'ş-Şât ile birlikte),thk., Ömer Hasen, Dimaşk 2011, c.1, s. 377-388.

40 bk.Karâfî, el-Furûk, c.1, s. 387. 
Karâfi diğer bir eserinde âdete göre farklılaşan hükümlere yer vererek şöyle demektedir: "Şerî̀atte âdetlere tabi olan konularda, âdetin değişmesi durumunda hüküm de buna bağlı olarak değişir. ${ }^{41}$ Karâfi'nin bu ifadesinde hükme nispet edilen değişim, âdetin değişmesine paralel olarak vuku bulan farklılaşma anlamındadır. Nitekim daha önce beyan edildiği gibi, âdetlerin değişmesi hükümlerin değişmesine değil, farklılaşmasına neden olmaktadır. Zira her âdet bir illete tekabül etmektedir. Her illetin özel bir hükmü var olduğu gibi, her âdetin de aldığı özel bir hüküm vardır. Her bir cüzî durum için özel bir hükmün bulunduğu bir yerde değişimden bahsetmek ise usulî kurallar açısından doğru değildir.

İbn 'Âbidîn'in hükümde değişim konusunda istidlâle konu edilen ifadelerini de şöyle değerlendirmek mümkündür: İbn 'Âbidîn’in bu konuda referans gösterilen ifadelerinden biri şöyledir: "Bil ki; fikhî meseleler iki kısma ayrılmaktadır. Bunlardan biri sarih nasla sabit olurken; diğeri bir ictihad türü ve réyle sabit olmaktadır. Bu son kısmın büyük bir bölümü, müçtehidin kendi zamao nında var olan örfe bina ettiği meselelerden oluşmaktadır. Öyle ki, onun zamanında yeni bir örf oluşmuş olsaydı, vermiş olduğu hükmün aksine hükümde bulunacaktı. Bu nedenledir ki, bilginler içtihadın şartlarını beyan ederken şöyle demişlerdir: Müçtehidin insanların örfünü bilmesi gerekir. Zira birçok hüküm zamanın değişmesiyle farklılaşmaktadır. Bunun nedeni ise, ya örfün değişmesi, ya bir zaruret halinin veya ahlakî bozulmanın meydana gelmesidir. Bu durumlar öyle bir hal alır ki, hüküm olduğu gibi bırakılırsa, insanlara zorluk ve zarar ilişir ve âlemin en güzel nizam üzere devam etmesi için kolaylık, zarar ve bozgunculuğun def'i üzerine bina edilen şer'î kurallara aykırı birtakım durumlar meydana gelir." 42

Bu ifadelere bakıldığında, diğer bilginlerde görülen benzer ifadelerin İbn 'Âbidîn tarafından da kullanıldı̆̆g görülür. O, bu ifadelerde örf için tagayyür kelimesini kullanırken hüküm için farklılık anlamına gelen ihtilaf kelimesini kullanmaktadır. Dolayısıyla bu ifadeler hükümde değișim konusu için bir delil teşkil etmemektedir. İbn Â̂bidîn başka yerlerde tagayyür kelimesini kullanıp hükme nispet etse de, ${ }^{43} \mathrm{o}$, bu ifadeden bilinen değişim anlamını değil, farklılaşma anlamını kast etmektedir. Konuya dair ifadelerini bir bütünlük içerisinde ele aldığımızda sözü edilen bu sonuç karşımıza çıkmaktadır. Kaldı ki, örfün söz konusu edildiği her yerde hükmüm değişmesinden bahsetmek doğru değildir. Zira örfler ilgili hükümlerin illetleri konumundadır. Hükümler illetlerle birlikte farklılaştığı gibi, örflerle birlikte de farklılaşmaktadır. Karâfînin, “Âdetlere terettüp eden hükümler, onların varlığıyla var olurken yokluğuyla da yok olmaktadır" ${ }^{44}$ şeklindeki sözleri bu hakikati ifadedir. Örf için söz konusu olan bu durum yukarıda yer verilen zaman, mekân, durum ve niyet gibi tüm değişkenler için de söz konusudur.

İbn 'Âbidîn tarafından "Yeminler örfe mebnîdir", "Yeminler örfi lafızlara bina edilir", "Amelî örf lafzî örf gibi itibara alınır” ${ }^{45}$ şeklindeki başlıklar altında yer verilen bilgi ve örneklerin tümü, örf ve âdetlerin lafızların delalet ve anlamları üzerinde etkili olduğunu ve bu tür lafızların delalet ettiği hükümlerin, lafızların bina edildiği niyet ve delaletlere göre farklılık gösterdiğini ifade etmektedir. Aynı konu daha önce diğer bilginler tarafından da ele alınmıștır.

41 Karâfî, el-İhkâm, s. 218.

42 İbn 'Âbidîn, Neşru'l-'Arf, c.2, s.125.

43 İbn 'Âbidîn, Şerhu Manzumeti 'Ukûdi Resmi'l-Muftî (Resâilu İbn 'Âbidîn içinde), c.1, s. 44, 45.

44 Karâfî, el-Furûk, c.1, s. 385.

45 bk. İbn 'Âbidîn, Muhammed Emin, Reddu'l-Muhtâr ala'd-Durri'Muhtâr, Beyrut 1992, c. 3, s. 379-712,743. 
Şâtıbî̉nin hükümde değişim konusunda istidlâle konu edilen ifadelerine gelince, bunları da şöyle değerlendirebiliriz: Şâtıbî âdetleri iki kısma ayırıp şöyle demektedir: "Devam eden âdetler iki türlüdür. Biri delilin ispat veya nefyettiği şer’i âdetlerdir. Bu, şu anlama gelmektedir: Şer', icab veya nedb olarak bu âdetleri emretmiş veya tahrim ve kerahet olarak onlardan nehyetmiştir veyahut da onların hem yapılması hem de yapılmamasına izin vermiştir. İkinci örf türü ise, insanlar arasında cari olup ispat veya nefyine dair herhangi bir şer'î delilin bulunmadiğı âdetlerdir." " ${ }^{6}$ Şâtıbî birinci tür âdetlerin diğer şer'î hükümlerde olduğu gibi, sabit ve daim olduğunu, Şâri' nezdinde güzel olan âdetlerin daima güzel kötü olanların da daima kötü olduğunu, buna karşın ikinci k1sım âdetlerin bazen sabit bazen de değişken olabildiğini ve bununla birlikte değişken âdetlerin hükümler için birer sebep teşkil ettiğini ifade etmektedir. ${ }^{47}$ Değişken âdetler için başı açık gezmek örneğini veren Şâtıbî konuşanların maksatlarını ifade eden ibarelerin de değişken âdetler içinde yer aldığını, zira ibarelerin meslekten mesleğe değiştiğini, manaya olan delaletlerinin de buna paralel olarak farklılaştığını beyan etmekte ve bu tür ibarelerin daha çok yemin, talak vs. akitler gibi konularda söz konusu olduğunu belirtmektedir. ${ }^{48}$

Şâtıbînnin bu ifadelerde dile getirdiği hususlar İbn Kayyim, Karâfi ve İbn Ẩbidîn tarafından dile getirilen hususlardan farklı değildir. Bu nedenle Şâtıbînin ifadeleri burada tekrar yorumlanmaya tabi tutulmamıştır. Kaldı ki, Şâtıbînin kendisi yukarıda yer verilen ifadeleri hakkında şöyle bir değerlendirmede bulunmaktadır: "Burada yer verilen 'âdetlerin farklılaşmasıyla hükümlerin farklıa laşması' hususu, hitabın aslında gerçek bir farklılaşmanın var olduğu anlamına gelmez. Çünkü şer' ebedî olmak üzere vaz’edilir ve dünya sonsuza dek devam etse-ki teklif de böyledir-şer'de yeni bir şeye ihtiyaç duyulmaz. Yukarıda ifade edilen ihtilaftan kasıt, buluğ örneğinde görülebileceği gibi, âdetlerin farklılaşması halinde her âdetin şer'î bir asla dönmesi ve ona göre hüküm almasıdır. Sözgelimi, teklifî hitap buluğ çağına erişmeyen çocuk için söz konusu değildir. Çocuk buluğa erişince teklife muhatap olur. Diğer bütün hükümler de böyledir. Binaenaleyh hükümler sabit olup sebeplerine tabidir." ${ }^{49}$

Şâtıbî̉nin bu değerlendirmesine bakıldığında, hükümde değişim diye ifade edilen hususun gerçek anlamda bir değişim olmadığı, aksine sebeplerin farlılığından kaynaklanan bir farklılık olduğu, şerîatın ebedî olmak üzere vaz’edildiği, dolayısıyla hükümlerin sabit olduğu ve değişimin hükümlerde değil, bu hükümlere sebep teşkil eden fiilî durumlarda cereyan ettiği görülür.

Şâtıbî̉nin mezkûr ifadelerinde yer verdiği "hitabın aslı" kavramından kastettiği şey, usulî anlamdaki hükümdür. Mükellefin fiillerine taalluk eden ve beş teklifi hükümden oluşan vücub, nedb, hürmet, kerahet ve helal hükümleri ise bu hitaptan alınan ve mükellefin fiillerine taalluk eden fıkhî hükümlerdir. Şâtıbî ve diğer fakihlerin sözünü ettikleri farklılaşma, yukarıda verilen örneklerden de anlaşıldığı gibi, usulî hükümde değil, fıkhî hükümlerde söz konusudur. Nitekim Şatıbînin, "Hükümler sabit olup her yerde sebeplerine tabi olmaktadır" ${ }^{50}$ şeklindeki sözleri yukarıdaki ifadelerinin bir özeti mahiyetindedir. Şâtıbînin hükmün aslında herhangi bir değişimin olmadığını vurgulayan ifadelerine benzer ifadeleri Ahmed Zerkâ, Fethî Ebu Sünne vd. birçok fakihte de görmek mümkündür. ${ }^{51}$

46 Şâtıbî, İbrahim b. Musa b. Muhammed el-Ğırnâtî, el-Muvafâkât, thk., Abdullah Draz, Beyrut, ty., c.2, s.283.

47 bk. Şâtıbî, el-Muvafâkât, c.2, s.283.

48 bk. Şâtıbî, el-Muvafâkât, c.2, s.283-284.

49 Şâtıbî, el-Muvafâkât, c.2, s.285-286..

50 Şâtıbî, el-Muvafâkât, c.2, s.286.

51 bk. Zerkâ, Mecelletu el-Müsslimûn, Sayı, 8, Yıl 1, Mayıs Temmuz 1954, s. 35; Ebu Sünne, el-Örfü ve’l-Âdetu fî R'eyi'l-Fukahâ, s. 161; Karadâvî, Yusuf, Şerîatu'l-İslam, Kahire 1993,s. 107-108; Bûtî, Muhammed Said, Davâbitu'l- 


\section{Mecelle'nin 39. Maddesi: “Zamanın Tagayyürü ile Ahkâmın Tagayyürü İnkâr Olunamaz"}

Mecelle heyeti tarafından 39. sırada yer verilen bu fıkhî kaide, ilk defa Hâdimî̀inin Mecâmi'u'lHakâik adlı eserinde görülmektedir. ${ }^{52}$ Burada, bu kurala yöneltilen lafzî ve manevî itirazları bir tarafa bırakıp ${ }^{53}$ ondan ne tür hükümlerin kast edildiği hususuna değinmek istiyoruz. Bu kuralla ilgili yapılan açıklamalara bakıldığında ondan kast edilen hükümlerin naslarda yer almayan örfî hükümler olduğu açıkça görülür. ${ }^{54}$ Dolayısıyla bu kuralda dile getirilen değişimden maksat, zamandan zamana, mekândan mekâna, bölgeden bölgeye, yöreden yöreye, meslekten mesleğe değişiklik arz eden örf ve âdetlerden kaynaklanan vaki durumlarda söz konusu olan değişimdir. Bu tür değişimin de, hükümde değişimi değil, hükümde farklılaşmayı gerektirdiği yukarıda detaylı olarak ele alınmıştır. Binaenaleyh bu kuralda sözü edilen değişimin de, hükümde değişim yerine, olguda değişimi konu edinen tahkîku'l-menât kapsamında ele alınması gerekmektedir. Bu kuralın izahı için verilen örneklere bakıldığında da bu hususu görmek mümkündür.

\section{Hz. Ömer'in Bazı Uygulamaları}

Hükümde değişimi savunanlarca ileri sürülen argümanlardan biri de Hz. Ömer'in bazı uygulamalarıdır. ${ }^{55}$ Müstakil çalışmalara konu olan bu uygulamaların burada detaylı olarak ele alınması çalışmamızın hem hacmi hem de amacı açısından mümkün değildir. Dolayısıyla burada mezkûr uygulamalardan bir örnekle yetinmek istiyoruz. $\mathrm{O}$ da hükmün değişimi konusunda çokça istidlâle konu edilen müellefetu'l-kulûb (kalpleri İslam’a 1sındırılmak istenen) meselesidir. Günümüzde de tartışılan bu meseleyi şöyle ifade edebiliriz: Zekâtın verildiği sekiz sınıftan biri de, İslam’a yeni girip kalpleri henüz itmi’nana kavuşmayan ve İslam’a ısındırılmaya (telîf) ihtiyaç duyulan müellefe-i kulûb sınıfıdır. İlgili zekât ayeti nazil olduktan sonra, Peygamber Efendimiz (s.a.v) bu sınıfa zekât vermeye başladı ve bu durum Hz. Ebubekir dönemine kadar devam etti. Hz. Ebubekir döneminin ilk başlarında da devam eden bu uygulama, muellefe-i kulûb oldukları gerekçesiyle zekât almak isteyen iki kişiye, Hz. Ömer'in engel olmasıyla birlikte uygulamadan kaldırılmış oldu. Mezkûr hükmün kaldırılma gerekçesi ise Hz. Ömer’in bu iki şahsa hitaben söylediği şu ifadelerinde yer almaktadır: "Resulullah İslam’n güçsüz ve Müslümanların az olduğu bir zamanda sizi müellefe-i kulûb sınıfı içinde kabul edip size zekât veriyordu. Ancak şimdi, Yüce Allah İslam’ı size ihtiyaç duymayacak kadar zengin ve güçlü kılmıştır. Gidin kendi işinize bakın." ${ }^{6}$

Hz. Ömer, “müellefe-i kulûb” sınıfina zekât verme hükmünün bağlandığı telif (İslam’a ısındırma) illetinin ortadan kalktığını mezkûr ifadelerinde yer vermiş olmaktadır. Zira bütün insanları muhatap alan İslam yayılmış, İslamî hüküm ve hakikatler toplumlar tarafından anlaşılmış

Maslaha fi’ş-Şerîati'l-İslamiyye, Beyrut 1986,s. 281, 291; Ğâmidî, Huza' b. Abdillah, Muhavelâtu't-Tecdid fî̀ Usûli'lFikh, Riyad 1429, c.2, s.828;Sufyânî, Âbid b. Muhammed, es-Sebâtu veşs-Șumûl fi'ş-Șerîati'l-İslamiyye, Mekke 1988, s.450,453,454,533,541; Muhammed Kemaluddin, İmam, Kavầidu Tagayyüri'l-Fetva Beyne'l-Hadesi'l-Kâin ve’zZemen:Kıraa Usuliyye(Nedvetu'l-Fıkhi'l-İslamî fî Âlemin Mutagayyir içinde),Umman 2012, s.133.

52 bk. Hâdimî, Menâfiu'd-Dekâik, s. 328.

53 bk. Nedvî, Ali Ahmed, el-Kavâidu'l-Fıkhiyye, Dimaşk 1991, s. 123; Karadâvî, Şerîatu'l-İslam, s. 107-108.

54 bk. Hadimî, Menâfiu'd-Dekâik, s.328;Ali Haydar, Şerhu Mecelleti’l-Ahkâm (Tảrîb:Fehmî Hüseynî), Riyad 2003, c.1, s.48; Zerkâ, Serhu'l-Kavâidi'l-Fikhiyye, Dimașk 1997, s. 227.

55 Mikdaş, Süha Selim, Tağayyürüll-Ahkâm fi'l-Fikhi'l-İslamî (Dirase Tatbikiyye li Kaideti Lâ Yünkeru Tağayyyüru'lAhkâm bi Tağayyüri'l-Ezman), BBeyrut 2007, s. 34; Devâlibî, Maruf, Mecelletu el-Müsslimûn, Sayı, 6, Yıl 1, Mayıs 1952, s. 35.

56 Cessâs, Ahkâmu'l-Kurân, Beyrut, t.y., c. 3, s. 123-124. 
ve Müslümanlar güçlü bir konuma gelmişlerdir. Dolayısıyla Müslümanların, bu sınıfı İslam’a 1sındırma ve kalplerini telif etme ihtiyaç ve iradeleri ortadan kalkmıştır. ${ }^{57}$ Aynı durum -illetleri farklı da olsa- zekâtın verildiği diğer sınıflar için de geçerlidir. Sözgelimi, zekâttan pay alan fakir sınıfının, zekât alma illeti olan fakirlik vasfı ortadan kalktığında, bu sınıfa fakirlik vasfıyla zekâtın verilmesi caiz değildir. ${ }^{58}$ Nitekim tüm sınıflara zekâtın veriliş nedeni, bu sınıfların zatları değil, taşıdıkları birtakım niteliklerdir. Zekât alma hükmüne gerekçe(menât) teşkil eden bu vasıflardan biri ortadan kalktığında, o sınıfa veya o sınıfın bir ferdine zekâtın verilmesi dinî açıdan mümkün değildir. Binaenaleyh Hz. Ömer'in bu uygulaması zannedildiği gibi, ${ }^{59}$ maslahatın değişmesiyle hükmün değişmesi değil, illetin ortadan kalkmasıyla ona bağlı olan hükmün ortadan kalkmasıdır. Usûlcülerin bu hususu tahkîku'l-menât yöntemi kapsamında ele almaları da bu hususu ifade etmektedir. ${ }^{60}$ Tahkîku'l-menât yöntemi ise yukarıda ifade edildiği gibi illetlere tekabül eden tikel vaki durumları inceleyen bir yöntemdir. Müctehid veya fakih bu yöntemi işletirken ilgili durumun, nastaki hükme konu olacak konumda olup olmadığını tespite çalışır ve bunun sonucunda tikel durum için uygun olan hükmü ortaya koyar.

Tahkiku'l-menât yöntemi açısında bu meseleye bakıldığında şunları söylememiz mümkündür: İlgili zekât ayeti iki hükmü içermektedir: Müellefetu'l-kulûb sınıfına girenlere zekât verilir. Bu sınıfa girmeyenlere bu isim altında zekât verilmez. Fakih/müçtehit bu ayeti vaki bir duruma/ tikel bir hadiseye uygulamak istediğinde ayetin menâtını (İslamı güçlendirmek için ilgili insanların kalplerini telif etmek) inceleyecektir. Vaki durumun ayetin kapsamına girdiğini görürse zekât verir. Aksi durumda zekât vermez. Hz. Ömer'in bu ayetle ilgili uygulaması da bundan başkası değildir. Zira O, telif gerekçesiyle zekât almak isteyen iki şahsın durumunu bu ayetin illeti açısından tahkik ediyor ve illetin bu kişiler hakkında tahakkuk etmediğini görüyor. Çünkü İslam yayılıp güçlenmiştir. Dolayısıyla ilgili şahısların kalplerinin telif edilmesine ihtiyaç kalmamıştır. Hz. Ömer bu içtihadından hareketle mezkûr şahıslara zekât vermekten vaz geçiyor. ${ }^{61}$ Binaenaleyh Hz. Ömer’in bu uygulaması, hükümde değişim yerine, olguda değişimi esas alan tahkîku'lmenât kapsamında mülahaza edilmesi gerekmektedir. Çünkü “müellefe-i kulûb” meselesinde Hz. Ömer'in tavrı, illetin değişmesinden kaynaklanan bir uygulamadır.

Hükümde değişimi kabul edenlerce çokça referans gösterilen bütün bu argümanlar görüldüğü gibi, hükümde değişim yerine, olguda değişimi temel alan ve her bir tikel olgunun ve ona uygun düşen hükmün tespit işlevini gören tahkîku’l-menât kapsamına girmektedir. Böylece hükümde değişimin ispatı sadedinde bu argümanlarla yapılan istidlâlin yerinde bir istidlâl olmadığı böylece ortaya çıkmış bulunmaktadır.

Burada şöyle bir itiraz akla gelebilmektedir: Şer'î hükümde gerçek anlamda bir değişim söz konusu olmasa da, mecazî veya zahirî bir değişim vardır. Bu nedenle hükümde değişimi savunanlar tarafından yer verilin mezkûr argümanlar hakikî değişimi değil, mecazî veya zahirî bir değişimi ifade etmektedir. Binaenaleyh hükümde değişim kavramının kullanıl-

57 bk. İbnu'l-Hümâm, Kemâluddin Muhammed b. Abdilvahid, Fethu'l-Kadîr, (Bidaye şerhi ile birlikte), Dâru'l-Fikr, Beyrut, t.y., c. 2, s. 259-261; Kubeysî, Mebâhisu't-Ta'lîl inde'l-Usûliyyîn ve'l-Gazalî (Basilmamış Doktora tezi), Mektebetu Camiati'l-Ezher (el-Meşîhatu'l-Ezheriyye), Resâil, 14, 251, HM, s. 66.

58 bk. Ensarî, Abdu'l-Aliyy Muhammed b. Nizamuddun, Musellemu's-Sübût (el-Mustasfâ ile birlikte), Mısır 1324, c. 2, s. 84; Bûtî, Davâbitu'l-Maslaha, s. 143-144.

59 bk. Şelebî, Ta'lîlu'l-Ahkâm, y.y., 1947. s. 37-38.

60 bk. Ensarî, Musellemu’s-Sübût, c. 2, s. 84.

61 Bu konuda daha geniş bilgi için bk. Beltâcî, Muhammed, Menhecu Ömer b. Hattâb fi't-Teşrî̀, Kahire 2006, s.148-160. 
masında herhangi bir sakıncanın söz konusu olmaması gerekir. Ancak bu itirazın iki açıdan yerinde bir itiraz olmadığını söyleyebiliriz: Birinci olarak: İslam hukuku değişimi asla yadsımaz. Bilakis değişimi insanî bir olgu olarak görür ve buna dair uygun birtakım çözümler vaz’eder. Ancak İslam hukukunun öngördüğü değişim hükümlerde değil, bu hükümlere konu olan tikel vaki durumlarda veya insanî faaliyetlerde söz konusu olmaktadır. Tikel vaki durumlardaki değişim ise hükümde değişim değildir. Çünkü her bir tikel vaki durumun kendine has bir hükmü vardır.

Hükümde değişim diye sunulan hususun gerçek anlamda değişim olmadığı hususu, tahkîku'lmenât yöntemine konu olan tikel vaki durumlardan anlaşıldığı gibi, nasların yapısından da anlaşılmaktadır. Şöyle ki, İslamî naslar iki açıdan tüm cüzî hadiseleri içeren bir yapıya sahiptir. Bunlardan biri nasları oluşturan lafız ve ifadeler. Diğeri de naslarda var olan vasıf ve nitelikler. Naslar bu iki yönüyle de bütün insanî faaliyetleri ve vaki durumları kuşatacak bir konumdadır. Bu nedenle naslar doğrudan veya delalet yoluyla her tikel hadise için bir hükmü içermektedir. Binaenaleyh cüzî hadiselerde gerçekleşen değişim, hükümde değişimi doğurmaz. Bu hususu somut bir örnekle izah edelim:

Her şer’î delil iki öncüle dayanır. Bu öncüllerden biri hükmün menâtını tahkik etmeye yöneliktir. Diğeri de şer’̂̀ hükmün kendisine yöneliktir. Birinci öncül olgusal konulardan oluşan fiilî durumları esas aldığından nazarîdir. İkincisi ise naslara dayandığından ötürü naklîdir. ${ }^{62} \mathrm{Bu}$ teorik bilgileri şer’î bir nas üzerinde tatbik etmek gerekirse, Şâri, "beyyine davacıya yemin de davalıya düşer" "63sseklinde bir hükümde bulunmaktadır. Bu hüküm tikel vaki bir duruma bina edilen şer'î bir hüküm olduğu gibi, tüm zaman ve mekânlarda da aynıdır. Burada değişime uğrayan ise bu hükme konu olan tikel durumlardır. Bu nedenle fakihin, bu tür naslarda hükme konu olan durumu tahkîku'l-menât yöntemi çerçevesinde inceleyip hükme bağlaması gerekmektedir. Sözgelimi, bir meslek sahibi, kendisine teslim edilen eşyanın kaybolduğunu; ancak kendisinin herhangi bir kusur veya ihmalinin bulunmadığını iddia eder de, eşya sahibi de aksini söylerse, fakihin meseleyi şer'î bir çözüme bağlaması için mezkûr yöntem çerçevesinde şöyle bir yol izlemesi gerekmektedir:

Fakih yaptığı inceleme sonucu meslek erbabının genelde doğru ve güvenilir olduğunu görürse, ilgili meslek sahibini haklı görür ve bu nedenle onu tazminle cezalandırmaz. Bu durumda mal sahibinin bu kişiye yemin ettirmekten başka bir hakkı yoktur. Fakih verdiği bu kararı yaptı̆̆ı şu içtihada/incelemeye dayandırmaktadır: Davacı, genel duruma aykırı bir davranışta bulunan veya galip zannın lehinde şahitlik etmediği kişidir. Davalı ise, sözü genel duruma aykırı düşmeyen veya genel durumun kendisini desteklediği kimsedir. Meslek erbabında da doğruluk ve güven egemen olduğu takdirde meslek sahibi davalı, mal sahibi ise davacı konumundadır. İlgili nasta belirtildiği gibi, mal sahibi bu durumda malının bir kusur veya ihmal sonucu telef olduğunu ispatlamak durumundadır. Aksi takdirde meslek sahibine yemin teklif etmekten başka bir şeyi yapma hakkına sahip değildir.

Fakih, zamanın değiştiğini ve ahlakî bozulmaların yaygınlaştığını görüp meslek erbabının da bundan e tkilenip teslim aldıkları mallar konusunda genelde doğru ve güvenilir olmadıkları kanaatine varırsa, ilgili meslek sahibini haksız görür ve vuku bulan telefte herhangi bir

62 bk. Hassan, Huseyn Hamid, Fikhu'l-Maslaha ve Tatbikatuhu'l-Mu'asıra, Cidde 1993, s. 21.

63 Şâfiî, el-Umm, Beyrut 1990, c, 3, s.56. 
kusurunun olmadığına dair ondan şahit/beyyine getirmesini talep eder. Aksi halde onu tazmine mahkûm eder. Meslek sahibi, suçsuzluğunu beyyine ile ispat etmediği takdirde, mal sahibine yemin teklif etmekten başka hukukî bir imkâna sahip değildir.

$\mathrm{Bu}$ örneğe dikkatlice bakıldığında, iki tikel vaki duruma dair verilen fetvanın değişmesine rağmen hükmün değişmediği görülür. Çünkü her iki durumda da, davacı ve davalıya aynı hüküm tatbik edilmektedir. Ancak davacı ve davalı konumunda bulunan mükelleflerin vaki durumları veya tikel pozisyonları yer değişebilmektedir. Nitekim sanatkâr bir pozisyonda davacı iken, diğer bir pozisyonda davalı durumuna düşmektedir. Buna karşın mal sahibi, bir pozisyonda davacı iken, diğer bir pozisyonda ise davalı konumuna düşmektedir. Davacı ve davalının pozisyonlarının yer değişmesine etki eden nedenler ise yukarıda belirtilen zaman, mekân, örf, âdet vb. beșerî ve olgusal değişkenlerden başkası değildir. Binaenaleyh İslam hukukunda kabul gören değişim hükümlerde değil, bu hükümlere konu olan tikel durumlardaki değişimdir. ${ }^{64} \mathrm{Bu}$ nedenledir ki, Zerkeşî, Şer'î hükümler kıyamete dek sabittir başlı̆̆1 altında, "Biz, zamanın değişmesiyle hükümler değişir(tă̆ayyür) yerine, hükümlerin taalluk ettikleri tikel suretler değişir deriz" demektedir. ${ }^{65}$ Zerkeşî Ömer b. Abdülaziz'den rivayet edilen, "İnsanlar yeni hadiselerin oluşmasına neden olduke ça, bu oranda yeni hükümler de oluşur" mealindeki sözünü de bu minvalde yorumlamaktadır. ${ }^{66}$ İşte tahkîku'l-menât yöntemi şer'î hükümlere konu olan meselelerde bu tür değişken durumları incelemektedir. Bu yöntem dünya devam ettikçe de devam edecektir. Çünkü meydana gelen yeni olgusal durumlar ve tikel sorunlar bu yöntem yoluyla fakihler tarafından çözüme bağlanmaktadır. Şâtıbî̀nin, "bu yöntemle yapılan içtihad kıyamete kadar devam edecektir"67 şeklindeki sözü bu hakikati ifade etmektedir. Dolayısıyla hükümde değişim konusuyla ilgilenenlerin bu konuyu, olgunun değişimini temel alan bu yönteme yönelmeleri bir zorunluluk olarak ortaya çıkmaktadır. İslamî hükümlerin evrensel olması da bu bağlamda anlaşılmalıdır. Binaenaleyh hükümde değişim kavramı, mecazî anlamında kullanılsa bile, yanlış algılamalara hatta birtakım yanılgı ve sapmalara yol açmaktadır. Kaldı ki, İslam hukukunda makbul olmayan birtakım çağrışımları ifade eden bu kavramı, değişim çağı diye anılan bir çağda mecazî anlamıyla kullanıp birçok çalışmaya konu yapmanın birçok hataya yol açacağı izahtan varestedir.

İkinci olarak: Hükümde değişim kavramı bazı araştırmacılar tarafından zahirî anlamında kullanılsa da, birçoğu tarafından gerçek anlamında kullanılmakta ve İslam hukukunda yeri olmayan alternatif hükümler bu kavramla tedavüle sokulmaktadır. Değişim kavramının bu türedi anlamına dair birçok örnek vermemiz mümkündür. Ancak amacımız örnekleri çoğaltmak olmadiğından üç örnekler yetinmek istiyoruz.

Konuya dair Fazlurrahman şunları kaydetmektedir: “İçtihat kural içeren bir nassın veya geçmişteki emsal bir durumun(precedent) manasını anlama ve o kuralı öyle bir şekilde teşmil, tahsis ya da aksi halde ta'dil ederek değiştirme çabasıdır ki, bulunan yeni çözüm vasitasıla yeni durumu içersin." ${ }^{8}$ Bu ifadelerde yer verilen "yeni çözüm” ve "yeni durum” ifadelerinden İslam hukukunda var olan hükümlerin alternatifleri kast edilmektedir.

64 Bu konuda geniş bilgi için bk. Bûtî, Muhammed Said, Davâbitu'l-Maslaha fi’ş-Şerîati’l-İslamiyye, Beyrut 1986, s. 281 292.

65 Zerkeşî, Bedruddin Muhammed b. Behadır, el-Bahru'l-Muhît fî Usûli'l-Fıkıh, yy., yt.,c.1,s.166.

66 bk. Zerkeșî, el-Bahru'l-Muhît, c.1, s.166.

67 Şâtıbî, el-Muvafâkât, c.4, s. 89-90.

68 Fazlurrahman, İslam ve Çağdaşlık (çev. Alpaslan Açıkgenç-Hayri Kırbaşoğlu), Ankara 1996, s.66. 
Maruf Devalibî bu konuda şöyle demektedir “İslam hukuku, Şâri” tarafindan neshedilmeyen bir hükmü değiştirme hakkını müçtehitlere tanımaktadır. Bu müçtehitler ister hâkim olsun ister müftî. Bunun nedeni de zamanın değişmesiyle birlikte değişen maslahatların elde edilmesidir. İslam hukukunun diğer semavî hukuklara üstünlüğü de burada tebarüz etmektedir." ${ }^{39}$ Devalibî, Kuran ve Sünnette yer alan hükümleri de kapsayan bu ifadelerin devamında, yukarıda zikredilen "Ezmanın tagayyürü ile ahkâmın tagayyürü inkâr olunamaz" kuralını da referans olarak göstermektedir. ${ }^{70}$

Muhammed Nuveyhî şer’î hükümlerin değişimi konusunda şunları söylemektedir: “ $K u$ ran ve Sünnette yer alan ve akîdeye ilişkin olmayan tüm teşrî̀ hükümler bizim için her zaman bağlayıcı değildir. Bilakis, Peygamber zamanında farz veya haram şeklinde bilinen hükümler bu gün bizim için bu konumda olmayabilir. Biz bu tür hükümleri nedb veya kerahete dönüştürebiliriz. Nebevî dönemde mendub veya mekruh olarak bilinen hükümleri de mubaha çevirebiliriz. Bizler, vaki durumların değiştiğine kani olduktan sonra bunu yapma hakkımız vardır. Kuran'ın ortaya koyduğu genel ahlakî gayelere bağlı kaldıkça...” ${ }^{71}$ Diğer iki alıntıda olduğu gibi, bu alıntıya göre de şer'î hükümler hitap ettiği toplumun tarihsel ve ictimaî koşullarıyla sınırlıdır. Kuran ve Sünnet tarafından belirlenen amelî-hukukî hükümler de buna dâhildir.

Mezkûr alıntılarda söz konusu olan yaklaşıma bakıldığında, hükümde değişim kavramının mecazî bir anlamda kullanılmasının fazla bir anlam ifade etmediği görülür. Çünkü Kuran ve Sünnetle sabit olan hükümlerin de dâhil olduğu tüm şer’î-hukukî hükümlerin değişebileceğini açıktan açığa teklif edildiği bir ortamda, bu kavramın ilmî temelden yoksun bir biçimde kullanılmasının sağlıklı bir yaklaşım olmadığı açıktır. Nitekim son dönemlerde ilmî mahfillerde tartışılan ve mevcut hukukî hükümlerin yerine birtakım alternatif hükümleri öneren tarihsellik tartışmaları da bu kavramın etrafında cereyan etmektedir.

Hükümde değişim kavramının Karâfî̀den İbn Âbidîn’e kadar birçok bilgin tarafından kullanıldığı ileri sürülerek bu gün de bu kavramın kullanılmasında bir sakıncanın olmadığı şeklindeki bir itiraza da şöyle cevap vermemiz mümkündür: Sözü edilen âlimlerin hükümler hakkında zaman zaman tagayyür kelimesini kullandıkları doğrudur. Ancak onlar bu kelimeden, ilk etapta anlaşılan anlamı kast etmemektedirler. Bilakis onlar bu kelimeyi ihtilaf kelimesiyle eş anlamlı olarak kullanmaktadırlar. İhtilaf kelimesi ise, daha önce ifade edildiği gibi, farklılaşma anlamını ifade etmektedir. Mezkûr bilginlere göre hükme konu olan fiilî durum veya tikel hadise farklılaşırsa hüküm de farklılaşır. Mantık ilminin terminolojisiyle ifade etmek gerekirse, şer’î önermelerde değişen husus, hükümlerden oluşan yüklemler değil, bu yüklemlere konu olan vaki durumlardır. Nitekim daha önce beyan edildiği gibi, her konu bir illeti ihtiva etmektedir. Her illetin de kendine özgü bir hükmü vardır. Bazı bilginler bu hususu, "değişim şer’î hükümlerin tatbikinde gerçekleşir” şeklinde ifade etmektedirler. ${ }^{72}$ Tatbik işleminin tahkîku’l-menât yöntemini işletmek suretiyle gerçekleştiği ise açıktır. Adı geçen bilginlerin ihtilaf ve tagayyür kelimelerini içeren ifadelerine ve bu bağlamda yer verilen örneklere birlikte bakıldığında bu anlamın kast edildiğini görmek mümkündür.

Hükümde değişimin gerçekte söz konusu olmadığını ifade eden bütün bu argümanlar, biraz

69 Devâlibî, Mecelletu el-Müsslimûn, s. 34 .

70 bk. Devâlibî, Mecelletu el-Müsslimûn, s. 34 .

71 Nuveyhî, Muhammed, Nahve Sevretin fi'l-Fikri'd-Dinî, Kahire 2010, s.149.

72 Ğarayânî, Sadık Abdurrahman, el-Hukmu'ş-Şer'iyyu Beyne’n-Nakli ve’l-Akıl, Beyrut 1989, s. 325. 
önce ifade edildiği gibi, İslam hukukunda hiçbir değişimin söz konusu olmadığı veya her türden değişimin reddedildiği anlamına gelmez. Bilakis İslam hukuku, fert ve toplum bazında insanî bünyeye arız olan tüm değişimleri kabul etmekte ve onlar için birtakım hüküm ve yöntemler vaz’etmektedir. Nitekim fetvanın değişim gerekçelerine bakıldığında, insanı ilgilendiren tüm durumların dikkate alındığı ve her bir durum için ayrı ayrı hükümler/çözümler vaz’edildiği görülmektedir. Daha açık bir anlatımla, fetvada söz konusu edilen değişim gerekçeleri, Müslüman fert ve toplumların yaşayabilecekleri ikamet hali-sefer, barış-savaş, sağlık-hastalık, zenginlik-fakirlik, emniyet-korku, bolluk-darlık, küçüklük-büyüklük, kırsal-şehir, sıcaklık-soğukluk, İslam diyarıküfür diyarı vb. tüm halleri kapsamaktadır.

Çalışmamızda vurgulamak istediğimiz şey ise, bütün bu hususların doğrudan hükmün değişimi bağlamında değil, hükme konu teşkil eden olguların değişimini inceleyen tahkîku'lmenât yöntemi kapsamında ele alınmasıdır. Çünkü yerleşik usule göre hükümde değişim diye müstakil bir konu yer almamaktadır. Son dönemlerde çokça tartışılan ve "Ezmanın tagayyürü ile ahkâmın tagayyürü inkâr olunamaz" şeklinde formüle edilen hükümde değişim konusu ise, İslam âleminde yaşanan yenilgiler sonucunda İslam hukukuna yöneltilen birtakım eleştirilerle birlikte gündeme gelmiştir. Asıl itibariyle örfe bina edilen hükümleri kapsamak için düzenlenen bu fikhî kural, yaşanılan yenilgiler ve yöneltilen eleştiriler sonucunda naslarda yer almayan hükümlere de teşmil edilecek bir konuma getirilmiştir. Salt örfî hükümleri kapsamak üzere Mecelle’ye alınan bu kural, İslam hukukunu savunma psikolojisiyle yaygınlık kazanmış ve bazı bilginler tarafından bütün hukukî hükümleri kapsayan bir konuma getirilmiştir. ${ }^{73}$ Bu kural, nerede ve nasıl işletilmesi gerektiği veya yerleşik usulde neye tekabül ettiği belirtilmeden sayısız çalışmalara konu edilmiş ve edilmeye de devam etmektedir. Günümüzden bir örnek vermek gerekirse, bir akademisyenin, “...Oysa sorun, ilk nüveleri Hz. Ömer'de, Ebu Hanife'nin 'istihsan' yönteminde ve Mutezile'nin 'nazar'ı her mümine vacip gören ve tarihte "Ehlu'r Rey" olarak isimlendirilen düşüncenin yerine, düşünceyi lafzi ibarelere sıkı sıkıya bağlayan "Edille-i Erbaayı" (Kitap, Sünnet, İcma, Kiyas), inancl, teslimiyeti ve taklidi esas kabul eden "Ashabu'l Hadis"in "Sünnilik (Şafiilik, Hanbelilik, Malikilik, Eşarilik ve Tasavvuf) olarak hâkimiyetinden, bunun yarattı̆̆ atmosferden kaynaklanmaktadır. İslam düşüncesinin, bugün bu handikabı aşması için, Batı'da geliştirilen ve teolojik kökleri Kuran'daki "nasih-mensuh”da ve Mecelle'nin 'usul' hükümlerinden olan "Ezmanın tağayyuru ile ahkâm tağayyur eder" ilkesinde bulunan "Tarihsel Kritik" yöntemi benimsememesinden kaynaklanmaktadır" "7s şeklindeki ifadelerine bakmak yeterlidir.

Hükümlerin nasıl tatbik edileceğini konu edinen usul ilmine bakıldığında ise bu mutlak ve muğlak kuralın yerine, dört başı mamur olan fetvada değişim kuralıyla illetlerin değişimi kuralının yer aldığ 1 görülür ki, her iki kural da hükümde değişim yerine olguda değişimi esas alan tahkîku’l-menât yöntemi kapsamında ele alınmaktadır. Dolayısıyla İslam hukukunda değişim konusu doğrudan hükümde değişim başlı̆̆ı altında değil, hükme konu olan olgu ve fiillerde değişimi konu edinen mezkûr yöntem çerçevesinde ele alınmalıdır. Bundan dolayıdır ki, usulcüler meydana gelen ve naslarda yer almayan hadiseleri bu yöntem kapsamında ele alıp çözmeye çalışmaktadırlar. Şâtıbînnin yukarıda yer verilen, “Bu yöntemle yapılan ictihad kıyamete kadar devam edecektir”75 şeklindeki ifadeleri bu hususu ifade etmektedir. Nitekim tahkîku'l-menât yöntemi

73 bk. Devâlibî, Mecelletu el-Müsslimûn, s. 34 .

74 Güler, İlhami, Yükselen selefilik ve tarihsel kritiğe olan ihtiyaç, Star Gazetesi(Açık Görüş), 06. Eylül. 2014.

75 Şâtıbî, el-Muvafâkât, c.4, s. 89-90. 
değişimi asla yadsımaz, aksine kabul eder. Fıkhı dondurmaz, aksine yeniler. Her tikel vaki durumu kendi özelinde ele alıp inceler. İncelerken de, zaman, mekân, durum, niyet, örf ve âdet gibi tüm beşerî değişken ve ilişenleri dikkate alır. Bu yöntem her cüz'î mesele için ayrı bir hükmü öngörür. Usulî bir ifadeyle söylemek gerekirse, İslam hukukunun mümkün hatta vaki ve zorunlu gördügü değişim, hükümlerde değil, bu hükümlere gerekçe teşkil eden illetlerdedir. Yerleşik usul bu hakikati "her hükmün bir illeti vardır", "hüküm varlıkta ve yoklukta illetle birlikte deveran eder” şeklindeki ifadelerle dile getirmektedir.

Hükümde değişim konusunda olduğu gibi son zamanlarda çokça tartışılan "dinde değişken ve sabiteler" veya "dinde makâsıd ve vesileler" konusunun da bu yöntemin kapsamında ele alınması gerekmektedir. Zira bu konu da olguda değişimi esas alan tahkîku’l-menât yöntemi kapsamına girmektedir. Nitekim bu konuya dair verilen örneklere dikkatlice bakıldığında bu hususu görmek mümkündür. ${ }^{76}$

Şimdi yukarıda yer verilen temel konuların yeterli düzeyde anlaşılmasına vesile olan tahkîku'l-menât yöntemine biraz daha yakından bakmaya çalışalım.

\section{Alternatif Çerçeve: Tahkîku’l-Menât Yöntemi}

Hukuka konu olan insan fiillerini veya tikel hukukî durumları ilgilendiren İslamî nasların çoğu genel ve soyut bir yapıya sahiptir. Naslara konu olan insan fiilleri ve cüzî hukukî durumlar ise dinamik bir mahiyet arz etmektedir. Bu da insan fiilleriyle cüzî hukukî durumların zaman, mekân, durum, âdet vb. beşerî ve tabiî değişken olgularla olan ilişkisinden ileri gelmektedir. Dolayısıyla naslar temelde mutlaklık ve değişmezlik gibi birtakım özellikleri taşırken; cüzî hukukî durumlar ve insanî faaliyetler görecelik ve değişkenlik gibi özellikleri taşımaktadır. Tahkîku'lmenât yöntemi ise karşıt özelliklere sahip olan naslarla cüzî durumlar arasında irtibat sağlayan bir köprü vazifesini görmektedir. ${ }^{77}$ Başka bir ifadeyle, bu yöntem nihaî tahlilde naslarda içkin olan hükümleri cüzî vaki durumlara ve insan fiillerine inzal etme işlevini görmektedir. Zira tahkîku'l-menât yöntemi, fikhî tikel bir hadiseyi vaki durum olgusu açısından incelemek ve bu vaki durumun sahip olduğu nitelikleri belirleyip uygun şer’î bir hükme konu yapmaktadır. ${ }^{78}$

Vaki durumlara tatbik edilmek için nazil olan şer’î hükümlerin tatbik işlemi ise, müşahhas/ cüzî konuların varlığını zorunlu kılmaktadır. Zira bir şey reelde varlık bulup müşahhas bir konuma bürünmedikçe hükme konu olması mümkün değildir. Hükme bağlanan bu cüzî konular insanın hayatın değişik alanlarında yaşadığı tikel vaki durumlardan başkası değildir. Mantık ve felsefede bu nitelikleri taşıyan cüzî varlık türüne haricî varlık vb. isimler verilmektedir. ${ }^{79}$ Fakih tarafından hükme bağlanmak istenen cüzî durumların mülahaza edilmesi, verilen hüküm açısından son derece önemlidir. Çünkü tasavvur edilmeyen bir şeyin hükme konu olması kabil değildir.

76 bk. Zuhaylî, Muhammed, es-Sevâbit ve'l-Mutegayyirât fi'ş-Şerîati'l-İslamiyye, Mekke 13: el-Muslimu'l-Mu’âsır ve'sSevâbit ve'l-Mutegayyirât) Mekke 2012, s,27-47; Atiyye, Cemaluddin, el-Vakı've'l-Misâl fi'l-İslami'l-Mu'âsır(Kadâyâ İslamiyye Mu'âsıra içinde), Beyrut 2001, s.208-220; Erdoğan, İslam Hukukunda Ahkâmın Değişmesi, s.100-107; Bûtî, es-Sevâbit ve'l-Mutegayyirât fi'l-İslam, Mecelletu Külliyeti’dirasâti'l-İslamiyye ve'l-Arabiyye, Sayı 4, Dubay 1992, s. 277 292.

77 Muhammed Kemaluddin İmam, Meâlâtu Tatbiki Menheci Tahkiki'l-Menât fî Te’cîli Ba'di'l-Ahkm ev Ta'likkiha, Sayı, 148, Yil, 2013, s. 109-124.

78 bk. Şâtıbî, el-Muvafâkât, (Diraz’in dipnotuyla birlikte), c. 4, s.89-90.

79 bk. Kangirî, Abdullah b. Şeyh Hasen, Nefâisu 'Ârâisi'l-Enzâr ve Letâifu Fevâidu’l-Efkâr (Fenârî Haşiyesi), Daru’tTibẩati'l-Âmire,1313, s. 224-225, 228. 
Şer'î hükümlere konu olan haricî-cüzî durumlar girift bir yapıya sahip olduğundan fakih tarafından ince elenip sık dokunmak durumundadır. Nitekim yeni oluşan bazı fiilî durumlar için uygun şer'î hükümlerin verilmemesi ya konunun doğru ve yeterli bir incelemeye tabi tutulmamasından veya fakih üzerinde etkili olabilen birtakım ferdî ve toplumsal etkenlerden ileri gelmektedir. Bir örnek vermek gerekirse, sevgililer gününü kutlamayı, yaygınlık gerekçesiyle umûmî belvâ kapsamına dâhil edip caiz olduğuna dair fetva vermek, tahkîku'l-menât yöntemi açısından mümkün değildir. Çünkü bu yöntem perspektifinden bu güne bakıldığında, meşru olmayan davranışları içeren mezkûr kutlamanın umûmî belvâ içinde değil de, fasit bir gelenek kapsamında değerlendirilmesinin gerekli olduğu görülür.

Müşahhas vaki durumlara uygulanan naslar da bir o kadar muhtelif bir yapıya sahiptir. Zira mutlak olup mukayyed anlamları ifade eden naslar söz konusu olduğu gibi, âmm olup has anlamlara delalet eden naslar da söz konusudur. ${ }^{80}$ Diğer bir ifadeyle, tahsise konu olan âmm naslar var olduğu gibi, mutlaklığı üzerinde bırakılması gereken mutlak naslar da vardır. Teklifi hükümlerin şart, mâni ve sebep gibi birtakım vaz’î hükümlere bağlanmasının bir nedeni de burada gizlidir. Dolayısıyla nasları anılan tikel-vaki durumlara tatbik etmeye çalışan fakihin, naslardan elde ettiği hükümlerle bu hükümlere konu olan tikel vaki durumları ince bir tahlile tabi tutması ve herhangi bir unsuru ihmal etmemesi gerekmektedir. Sözgelimi, fakih mutlak nasları takyit etmeden veya genel anlamlı nasları tahsis etmeden tikel vaki durumlara tatbik etmeye kalkışırsa yanlış hüküm vermiş olacak ve bunun sonucunda naslarla elde edilmek istenen birçok şer’î maslahat zayi olacaktır. Nitekim her şer'î hüküm muayyen birtakım dünyevî veya uhrevî maslahatlara mebnîdir.

Tahkîku'l-menâtın önemli bir boyutunu oluşturan vaki durumun girift bir yapıya sahip olmasının temel nedeni de, yukarıda beyan edilen zaman, mekân, durum, âdet ve niyet gibi değişim unsurlarını ihtiva etmesidir. Fetvaya konu olan hukukî sorunların niteliklerini oluşturan bu unsurlar fakih tarafından doğru bir biçimde tespit edilmeden isabetli fetvaların söz konusu olması mümkün değildir. Zira mezkûr unsurlar, tahkîku'l-menât yöntemiyle tespit edilmeye çalışılan vaki durumların niteliklerinin değişmesine etki etmektedir. Fetvanın değişimine neden olan bu nitelikler de hükmün bağlandığı illetlere tekabül etmektedir. Bu nedenledir ki, Âmidî, tahkîku’l-menâtı, "hükk me konu teşkil eden her hadisede illetin varlı̆̆ını bilmektir" ${ }^{\prime 1}$ şeklinde tanımlamaktadır. Dolayısıyla hukukî bir sorunla karşılaşan fakihin, bu sorunu mezkûr değişim unsurları açısından incelemesi ve ona göre hükümde bulunması gerekmektedir. İbn Kayyim’in, "Her kim insanların ait oldukları örf, âdet, zaman, mekân, durum vb. değişkenleri göz ardı edip sadece kitaplarda yazılı olanlarla fetva verirse, hem sapmış hem de saptırmış olur. Bu tip fetva veren birinin dine karşı işleyeceği cinayet, zaman, mekân, âdet ve tabiatları itibara almadan tıp kitabında yazılı olanlarla bütün insanları tedavi eden tabibin cinayetinden daha büyüktür. Insanların canına ve dinine yönelebilen en büyük tehlike bu tip cahil tabib ve müftilerden gelmektedir" ${ }^{22}$ mealindeki ifadeleri fetva değişimine tesir eden mezkûr unsurlara riayet etmenin ne denli önemli olduğunu nazara vermektedir.

Şer’î hükümlere konu teşkil eden tikel vaki durumları inceleme işlevini gören tahkîku'lmenât yöntemi, bu işlevi birtakım yollarla yapmaktadır. Vaki durumları inceleme kriterleri diyebileceğimiz bu yollar lugavî, örfî, hissî, aklî ve tabiî olmak üzere beş ana kategoriden oluşmak-

80 Bu konuda geniş bilgi için bk. Şâfiî, er-Risâle, s. 53-72.

81 Âmidî, el-íhkâm, c.3, s.302.

82 İbn Kayyim, İlâmu'l-Muvakki'în, c.3, s. 71. 
tadır. ${ }^{83}$ Vaki durumları tanıma ölçütleri şeklinde de isimlendirilebilen bu yollar şer’î hükümlere konu olan tüm vaki durumları kapsar niteliktedir. Burada bütün bu ölçütleri detaylı olarak ele alma imkânımız söz konusu olmadığından her birine dair bir örnek vermekle yetinmek istiyoruz. Yolculuk, fakirlik, zenginlik, yakınlara verilen nafaka vb. konular örfi ölçütün kapsamına girmektedir. Vahyin nazil olduğu vasatta anlamları bilinen lafızlar lugavî örfün örneğini oluşturmaktadır. Buğday, arpa vb. gıda maddeleri hem hissî hem tabiî ölçütler için birer örnek teşkil etmektedir. Maslahat ve mefsedetler aklî ölçütler kapsamına girmektedir. Buluğ ve çocukluk örneklerinde görüldüğü gibi biyolojik konular his ve tabiatın birer örneği olarak zikredilebilir. ${ }^{84}$ Bütün bu yollar tikel vaki durumlarda illetin varlığını gösterse de, illetin zat ve vasfını belirleyip hükmün ona bağlanması nihaî kertede şer'î delillerle mümkün olmaktadır. Zira şer'î illet zatı gereği hükmü gerektirmemektedir. Diğer bir ifadeyle illetin illet olması Şâri’in vaz’nna bağlı bulunmaktadır. Bunu öğrenmenin yolu da şer'î delillerden geçmektedir. ${ }^{85}$

Vaki durumları inceleyen bu yollar idrak edilme, ele alınma, bilinme düzeyi vb. hususlarda birbirinden farklılık arz etmektedir. Şöyle ki; hissî konularda görüldüğü gibi bazı vaki durumların idraki kolaydır. Lafızların anlamlarında görüldüğü gibi bazı vaki durumların bilinmesi için sözlük bilgisine ihtiyaç duyulmaktadır. Örf ve âdet konularında olduğu gibi bazı vaki durumlar tecrübe ve uzmanlık gerektirmektedir. Muamelat ve akitlerde müessir olan maslahat, zarar, zaruret, ihtiyaç vb. hususlarda görüldüğü üzere bazı vaki durumların idraki zordur. Öyle ki, her fakihin bu tür konularda doğru bir tahkik ve inceleme imkânına sahip olması düşünülemez. Nitekim günümüzde hukukî, ilmî, ticarî, iktisadî, ailevî, eğitim vb. birçok alanda tahkik edilip şer'î hükümlere bağlanması istenilen birçok vaki durumun veya hukukî sorunun, muhtelif branşlara sahip bilginler tarafından incelenmesinin ön plana çıkması hatta zorunlu bir hal alması da buradan kaynaklanmaktadir.

\section{Sonuç}

Sonuç olarak diyebiliriz ki, son dönmelerde yaygın bir biçimde tartışılan hükümde değişim, ahkâmın değişmesi vb. kavramlar usûlî temellere bina edilmeden ele alınmaktadır. Hükümde değişimin ispatı sadedinde ileri sürülen tüm argümanlar bu konuya ait olmadığg gibi, konuya dair verilen örnekler de bu alana ait değildir. Bütün bu argüman ve örnekler olguda değişimi esas alan tahkiku'l-menât yöntemi kapsamında ele alınan vaki durumların değişiminden bahsetmektedir.

Tahkîku'l-menât yöntemi şer’î hükümlere konu teşkil eden bütün vaki durumları ve insan fiillerini kapsayan ve belli başlı alt yolları bulunan usulî bir yöntemi ifade etmektedir. Karâfîden İbn 'Âbidîn’e kadar hükümde değişim konusuna yer veren tüm fakihler, günümüzde değişim kavramından anlaşılan anlamı kast etmemişlerdir. Bilakis onlar tagayyür kelimesini farklılık anlamına gelen ihtilaf kelimesiyle eş anlamlı olarak kullanmışlardır. Başta İbn Kayyim olmak üzere mezkûr bilginlerce yer verilen fetvada değişim kavramıyla örfte değişim kavramı, sanıldığının aksine hükümde değişime tekabül etmemektedir. Bu kavramlar hükümde değişimden ziyade fiilî durumlarda değişimi ifade etmektedir.

83 bk. Bin Beyye, el-İctihad bi Tahkîki'l-Menât: Fikhu'l-Vâkı've't-Tevakku', http: // www. binbayyah. net/portal/rese$\operatorname{arch} / 1148$.

84 bk. Bin Beyye, el-İctihad bi Tahkîki'l-Menât: Fikhu'l-Vâki've't-Tevakku', http: // www. binbayyah. net/portal/rese$\operatorname{arch} / 1148$

85 bk. Gazalî, el-Mustasfâ min İlmi'l-Usûl (Fevâtihưr-Rahamût ile birlikte), Bulak 1324, c. 2, s. 280. 
Fetvanın değişim gerekçeleri olarak zikredilen zaman, mekân, durum, âdet ve niyet gibi tikel vaki durumlar hükmün bağlandığg şer’î illetlere tekabül etmektedir. Her illetin kendine özgü bir hükmü var olduğu gibi, her vaki durumun da kendine özgü bir hükmü vardır. Hükümler varlık ve yoklukta illetlerle birlikte deveran ettiği gibi, cüz'̂̀-vaki durumlarla birlikte de deveran etmektedir. Cüzî-vaki durumları inceleyen tahkîku'l-menât yönteminin işlevi hükümlere bağlanan bu tikel olgusal durumların tespiti noktasında ortaya çıkmaktadır. Fukaha hükümde değişim kavramı yerine fetvada değişim ve illetlerde değişim kavramlarını kullanmaktadır. Günümüzde de aynı kavramların kullanılması usûlî bir zorunluluk olarak karşımıza çıkmaktadır. Değişim konusunda yapılan çalışmaların sağlam ilmî temellere ve usûlî yöntemlere bina edilebilmesi için bu çalışmaların tahkîku'l-menât yöntemi kapsamında ele alınması zorunludur.

Hükümde değişim kavramı birçokları tarafından müsellem bir hakikat olarak telakki edilip bütün hükümlere teşmil edilmektedir. Son zamanlarda çokça tartışılan ve tüm şer'î-amelî hükümleri kapsayan tarihsellik konusu bu kavrama dayandırılmaktadır. Hangi alanlarda ve nasıl işlev göreceği belirlenmeyen bu fikhî kuralın, tahkîku'l-menat yönteminden bağımsız olarak ele alınması, İslam hukukunda bir yöntem dâhilinde kabul edilen değişimin aslî mecrasından çıkıp farklı mecralara girmesi ve sonucu kestirilemeyen birtakım yanılgı ve saplantılara yol açması kaçınılmazdır.

\section{Kaynaklar}

Ali Haydar, Şerhu Mecelleti’l-Ahkâm (Ta’rîb: Fehmî Hüseynî), Riyad 2003.

Allâm, Şevkî, Davâbitu'-Ifftâ fi'l-Vaki'i'l-Mu'âsır: Menheciyyetu Sina'ati'l-İftâ (3), http://www. ahram.org.eg/NewsPrint/288382.aspx.

Davâbitu'-İftâfi'l-Vaki'il-Mu'âsır:MenheciyyetuSina'ati'l-İftâ(5), http://www.ahram.org. eg/NewsPrint/288382.aspx.

Âmidî, Ali b. Muhammed, el-İhkâm fî Usûli’l-Ahkâm, thk., Abdurazzak 'Afıfî, Beyrut 1402.

Atiyye, Cemaluddin, el-Vakı've'l-Misâl fi'l-İslami'l-Mu'âsır(Kadâyâ İslamiyye Mu'âsıra içinde), Beyrut 2001.

Beltâcî, Muhammed, Menhecu Ömer b. Hattâb fi't-Teşrî̀, Kahire 2006.

Binbeyye, Abdullah, Sinâ’atu'l-Fetva ve Fikhu'l-Evveliyyât,Cidde 2007.

el-İctihad bi Tahkîki'l-Menât: Fıkhu'l-Vâki’ve’t-Tevakku', http: // www. binbayyah. net/ portal/research/1148.

Bûtî, Muhammed Said, Davâbitu’l-Maslaha fiş-Şerîati'l-İslamiyye, Beyrut 1986.

es-Sevâbit ve'l-Mutegayyirât fill-İslam, Mecelletu Külliyeti' dirasâti'l-İslamiyye ve'l-Arabiyye, Sayı 4, Dubay 1992.

Cessâs, Ahkâmu'l-Kur'ân, Daru'l-Kitâbi'l-Arabî, Beyrut, t.y. c.

Cuma, Ali, et-Te'sîlu'l-Hadarî li't-Teşrî̀i'l-İslamî(Tağayyürü'l-Fetva), http://pathlandmarks. blogspot.com.tr/2012/01blog-post.html

Devâlibî, Maruf, Mecelletu el-Müsslimûn, Sayı, 6, Y1l 1, Mayıs 1952.

Ebu Sünne, Ahmed Fehmî, el-Örfü ve'l-'Âdetu fî R'eyi'l-Fukahâ, Kahire 2004.. 
Ensarî, Abdu’l-Aliyy Muhammed b. Nizamuddun, Musellemu's-Sübût (el-Mustasfâ ile birlikte), Matbaatu'l-Emîriyye, Misir 1324.

Erdoğan, Mehmet, İslam Hukukunda Ahkâmın Değişmesi, İstanbul 1994.

Fazlurrahman, İslam ve Çağdaşlık (çev. Alpaslan Açıkgenç-Hayri Kırbaşoğlu), Ankara 1996.

Gazalî, el-Mustasfâ min İlmi’l-Usûl (Fevâtihu'r-Rahamût ile birlikte), Bulak 1324.

Ğâmidî, Huza' b. Abdillah, Muhavelâtu't-Tecdid fî Usûli'l-Fıkh, Riyad 1429.

Ğarayanî, Sadık Abdurrahman, el-Hukmu'ş-Şer'iyyu Beyne’n-Nakli ve’l-Akıl, Beyrut 1989.

Hâdimî, Ebu Said Muhammed, Menâfiu'd-Dekâik fî Şerhi Mecâmi'i’l-Hakâik, İstanbul 1305.

Hasan, Mahmud Abdulkerim, Tahrifu'l-İslam bi Hücceti Tagayyüri'l-Ahkâm bi Tagayyüri'zZemani ve'l-Mekan(2), http://sabiltahrir.blogspot.com.tr/2013/06/2.html.

Hassan, Hüseyn Hamid, Fıkhu'l-Maslaha ve Tatbikatuhu'l-Mu'asıra, el-Ma'hedu'l-İslamî li'lBuhûs, Cidde 1993.

İbn ‘Âbidîn, Muhammed Emin, Reddu’l-Muhtâr ala'd-Durri’l-Muhtâr, Beyrut 1992.

İbn ‘Âbidîn, Şerhu Manzumeti 'Ukûdi Resmi’l-Muftî (Resâilu İbn ‘Âbidîn içinde), İstanbul 1320. Neşru'l-Arf fi Binâi Ba'di’l-Ahkâm ala'l-Örf (Macmu'atu Resâili İbn Abidîn içinde), İstanbul 1320.

İbn Hâcib, Ebu Amr Osman, Münteha'l-Vusûl ve'l-Emel fi İlmeyi'l-Usûl ve'l-Cedel, Misır 1326.

İbn Kayyim, Ebu Abdillah, Muhammed b. Ebibekr, I'lâmu'l-Muvakki'în 'an Rabbi'l-Alemîn, thk., Muhammed Mu’tasım el-Bağdadî, Buyrut 1996.

İbn Kayyim, İğâsetu'l-Lehfân min Mesâyidişş̧eytân, thk., Muhammed Hamid el-Fukâ, Riyad, t.y.

İbn Nüceym, Zeynüddin b.İbrahim, el-Eşbâh ve’n-Nezâir, thk., Muhammed Muti' Hafız, Dimaşk 2005.

İbnu'l-Hümâm, Kemâluddin Muhammed b. Abdilvahid, Fethu'l-Kadîr, (Bidaye şerhi ile birlikte), Dâru'l-Fikr, Beyrut, t.y.

Kubeysî, Mebâhisu't-Ta'lîl inde'l-Usûliyyîn ve'l-Gazalî (Basılmamış Doktora tezi), Mektebetu Camiati'l-Ezher (el-Meşîhatu'l-Ezheriyye), Resâil, 14, 251, HM.

Kangirî, Abdullah b. Şeyh Hasen, Nefâisu 'Ârâisi'l-Enzâr ve Letâifu Fevâidi'l-Efkâr (Fenârî Haşiyesi), Daru’t-Tibâati’l-Âmire,1313.

Karadâvî, Yusuf, Serîatu'l-İslam, Kahire 1993.

Karâfî,Şihâbuddin Ebu'l-Abbas Ahmed b. İdrîs, el-İhkâm fî Temyîzi'l-Fetavâ 'ani'l-Ahkâm ve Tasarrufati'l-Kâdî ve'l-İmâm,thk., Abdulfettâh Ebu Gudde, Beyrut 2009.

el-Furûk (İbnu'ş-Şât ile birlikte),thk., Ömer Hasen, Dimaşk 2011.

Kubeysî, Hamed Ubeyd, Usûlu'l-Ahkâm ve Turuku'l-İstnbât fi't-Teşrî̀i'l-İslamî, Dimaşk 2009.

Mensî, Muhammed Kasım, Tağayyürü'z-Zurûf ve Eseruhu fî İhtilafi'l-Ahkâm, Kahire 2010.

Mikdaş, Süha Selim, Tağayyürü'l-Ahkâm fi'l-Fıkhi'l-İslamî, Beyrut 2007. 
Muhammed Kemaluddin İmam, “Meâlâtu Tatbiki Menheci Tahkiki’l-Menât fî Te’cîli Ba'di'lAhakm ev Ta'lîkiha”, Mecelletü'l-Müslim el-Mu’âsır,Sayı, 148, Yıl, 2013.

Kavâ'idu Tagayyüri'l-Fetvâ Beyne'l-Hadesi'l-Kâin ve’z-Zemen:Kıraa Usuliyye(Nedvetu'lF1khi'l-İslamî fî Âlemin Mutagayyir içinde),Umman 2012.

Narânî, Halil Mahmud, Eseru’z-Zarffî Tağyîri'l-Ahkâmi’ş-Şer'iyye, Nablus 2003.

Nedvî, Ali Ahmed, el-Kavầidu’l-Fıkhiyye, Dimaşk 1991.

Nuveyhî, Muhammed, Nahve Sevretin fi'l-Fikri'd-Dinî, Kahire 2010.

Râzî, Kutbuddin Muhammed b. Muhammed, Levâmi'u'l-Esrâr fî Şerhi Metâli'i’l-Envâr, Matbaatu'l-Hâc Muharrem Efendi, yy., 1303.

Reysûnî, Kutub, Sinẩatu'l-Fetva fi'l-Kadâya'l-Mu'âsıra, Beyrut 2014.

Senûsî, Abdurrahman, I'tibarâtu'l-Meâlât ve Mura'âtu Netâici't-Tasarrufât, yy., 1424.

Susere, Abdulmecid Muhammed, el-Hukmu'ş-Şer'iyyu Beyne’s-Sebâti ve't-Tagayyür, Mecelletu'ŞŞerîa ve'l-Kanun, Sayı 20, Eylül 2003.

Sufyânî, Âbid b. Muhammed, es-Sebâtu veş-Şumûl fiş-Şerîati'l-İslamiyye, Mekke 1988.

Şâfî̀, er-Risâle, thk., Ahmed Şâkir,yy., t.y. el-Umm, Beyrut 1990.

Şâtıbî, İbrahim b. Musa b. Muhammed el-Ğırnâtî, el-Muvafâkât, thk., Abdullah Diraz, Beyrut, t.y. Şelebî, Mustafa, Ta'lîlu’l-Ahkâm, Matbaatu'l-Ezher, y.y. 1947.

Uraynî, Ahmed b. Süleyman, en-Nehcu'l-Akvâ fî Erkâni’l-Fetvâ, Riyad 2008.

Yaman, Ahmet, Fıkhın Sosyolojik Yürürlüğü Bağlamında Fetvada Değişim, Diyanet İlmi Dergi, Nisan-Mayıs-Haziran 2014, 50/2.

Zerkâ, Mustafa Ahmed, el-Medhalu'l-fikhiyyu’l-'amm, Dimaşk 1968.

Mecelletu el-Müsslimûn, Sayı, 8, Y1l 1, Mayıs-Temmuz 1952. Şerhu'l-Kavâidi'l-Fıkhiyye, Dimaşk 1997.

Zerkeşî, Bedruddin Muhammed b. Behadır, el-Bahru'l-muhît fî usûli'l-fıkıh, yy., y.t.

Zuhaylî, Muhammed, es-Sevâbit ve’l-mutegayyirât fiş-şerîati'l-İslamiyye, (Mu'temeru Mekke 13: el-Muslimu'l-mu'âsır ve's-sevâbit ve'l-mutegayyirât), Mekke 2012. 